\title{
A comparative study of formulaic expressions in textbooks of Turkish as a foreign language
}

\author{
Nahide Arslan ${ }^{* a}$, Mustafa Mavaşoğlu **b \\ ${ }^{a}$ Uludag University, Faculty of Education, Bolu/Turkey \\ ${ }^{b}$ Cukurova University, Faculty of Education, Adana/Turkey
}

Article Info

DOI: $10.31704 /$ ijocis.2018.008

Article History:

Received 14 July 2018

Revised 21 October 2018

Accepted 26 November 2018

Online 24 December 2018

Keywords:

Turkish as a foreign language, Speech acts,

Formulaic expressions.

Article Type:

Research paper

\section{Abstract}

The aim of this study was to examine, in a comparative way, formulaic expressions used in textbooks of Turkish as a foreign language and to determine in which contexts and how often they are included in these textbooks. Survey model was used to obtain data from three textbooks of Turkish as a foreign. Formulaic expressions in these books were collected then analyzed in terms of their structural, functional, semantic and contextual features. 193 expressions that met criteria of being formulaic expressions were determined as sub-categories in the textbooks and workbooks and linked to 21 speech acts that were grouped as main categories. Results showed that textbooks may have difficulties in providing a balanced representation of interrelated formulaic expressions, a number of formulaic expressions cannot be included in textbooks although they are frequently used in everyday life and informational contents about speech acts and formulaic expressions in textbooks can be represented being carried into workbooks but they are not reinforced as they are less used in workbooks. Based on these results, suggestions were made both for authors of future textbooks and workbooks of Turkish as a foreign language and authors of future studies concerning formulaic expressions and Turkish as a foreign language.

\begin{tabular}{ll}
\hline \multicolumn{2}{c}{ Yabancılara Türkçe öğretimi ders kitaplarındaki kalıpsözlerin karşıllaştırmalı } \\
incelenmesi
\end{tabular}

** Author: nahiarslan@hotmail.com
Author: mumavas@gmail.com
Orcid ID: https://orcid.org/0000-0003-0437-0722 Orcid ID: https://orcid.org/0000-0003-3410-6690 


\section{Introduction}

Every individual belonging to a nation carries the culture, language, religion, beliefs, customs and traditions of that nation. As two parts of a whole which are impossible to be separated, language and culture exist simultaneously and interconnected. As Güvenç (1996) emphasizes, it is culture that feeds language, and what exists in language also exists in culture. Language is the reflection and habitat of culture. The cultural richness, consciousness and originality of a society are echoed in language. For this reason, language is one of the most robust and indispensable indicators of the culture of a society and therefore of the way of life.

Since language and culture are not thought to be separated from each other, they are interdependent and interconnected in interaction. The relationship between these two entities can be clarified by using various tools. Formulaic expressions are one of these tools. As "language elements that shed light on our attitude" (Bulut, 2012, p.1118), formulaic expressions are linguistic communication tools that provide emotion transfer and interaction in important situations in human and community life such as birth, marriage and death (Özdemir, 2000).

Every society has its own expressions in certain situations that are mentioned in specific cases. These expressions have to be used in certain circumstances, in a particular context, under certain conditions. Vardar (2002) refers to two types of context: internal context and external context. Internal context or intralinguistic context is "a unit or set of units that surround a linguistic unit, precede or follow it, influence it in several situations, determine its meaning and value" (p.30). External context or extralinguistic context is defined as "all data on the situation, and the non-linguistic, social, cultural and spiritual experience and knowledge of the speaker and the listener" (p.30). Formulaic expressions that cannot be thought to be free from context are evaluated in two ways: formulaic expressions with intralinguistic context and formulaic expressions with extralinguistic context.

Formulaic expressions with intralinguistic context may correspond to a previous expression and a continuation of expressions mentioned during the conversation as well as before expressions and thoughts to be transferred later. Inşallah, Allah daim etsin, Allah muhtaç etmesin, etc. expressed in the sense of positive thoughts and wishes, Hayrolsun, Allah korusun, Hafazanallah, Allah esirgesin, Maşallah, etc. expressed to get rid of evil, Allah büyük, Ağzını hayra aç, Gün doğmadan neler doğar, Allahın dediği olur, etc. in some cases, when you can't be sure, take refuge in a great power and hope for something and to prevent possible negativity can be shown as examples of formulaic expressions.

A situation or environment must be formed so that formulaic expressions with extralinguistic context can be said. In Turkish, the formulaic expression bir yastıkta kocayın is said to married couples; it is not said to new friends. Otherwise it leads to a meaningless expression that cannot be established. Formulaic expressions are a series of sayings in which good opinions are expressed, allowing individuals of a society to keep their relationships alive and dynamic. They make interpersonal relationships vivid and sustainable. It is precisely for this reason that Aksan (1996, 2000, 2002, 2003, 2005a, 2005b, 2008) defines formulaic expressions as relationship expressions. According to him, formulaic expressions or relationship expressions are words that have been tradition to be said in certain situations in every society, patterns or various stereotypes that reveal emotions and non-linguistic elements are mostly used to describe and explain these expressions $(2013$, p.163). Similarly, Bilgin (2006) defines formulaic expressions as "customary expressions to be said in certain situations" (p. 75).

Kula (1996) thinks that expressions that are used in certain communication situations such as good wishes, condolences, birth, separation etc. are culture units (formulaic expressions) and they tell us about Turkish culture. According to him, these expressions are the nomenclature where language culture becomes evident.

Çotuksöken (1994) argue that formulaic expressions are mainly made up of non-language contexts. Formulaic expressions are "words used in various contexts among the members of a society such as thanking, apologizing, requesting, meeting, welcoming/seeing off a passenger, voicing a request" (p.28). According to him, formulaic expressions can be called contextual words or words of welcome.

\section{Speech Acts}

Formulaic expressions are part of communication which is in vocabulary and that humans realize with language. Formulaic expressions are used in everyday language, during oral communication, in written texts, decorated with the culture of the nation who speaks the same language. These are stereotyped units in form of words or sentences. Austin and Searle are the first researchers to address the concept of formulaic expressions within the framework of the theory of speech acts. The theory of speech acts is a theory of language philosophy 
created by Austin and his student, Searle. Formulaic expressions are part of the theory of speech acts, a theory of language, and the smallest units of communication that man performs with language. According to Austin (1970), "to say something is to do something" (p.15). In other words, while speaking, a speaker simultaneously performs an act. Thus, linguistic communication is not only about transmitting a message, but also has a performative function. In the concept of speech act, act refers to action while speech refers to language (Çelebi, 2014).

Austin developed these thoughts on the relationship between speech and act, based on Wittgenstein who believed that speech is a certain form of action and words or expressions will gain meaning only through their use in sentences. It is very important to know the context in which it is used, its place, its time, and to whom it is said in order to understand any speech.

According to Austin (1970), there are three kinds of speech acts: locutionary, illocutionary and perlocutionary. Locutionary act is a grammatical speech act that does not need extralinguistic units in its interpretation and explanation (Vardar, 2002). When it comes to illocutionary and perlocutionary acts, both are based on locutionary acts. Illocutionary act is the simultaneous occurrence of the speech and the action implied by the speech of the speaker. In other words, speech and action are synonymous in illocutionary act (such as war announcement, etc.). In this case, there is indirectness between speech and act. In perlocutionary act, the speaker has an intention to indirectly influence the listener (such as persuasion and deterrence). In other words, perlocutionary act is an act which aims to influence the listener, depending on the intent of the speaker (Kıran \& Kıran, 2013).

Locutionary act is an act of speech production. It is lexical, morphological and syntactic. To say something is to produce meaningful units of a vocabulary, to place them in a meaningful order according to a grammar. In short, locutionary act is to produce sentences through grammatically correct words. According to Austin (1970), phonetic, phatic and rhetic acts are also realized with locutionary act. Phonetic acts are performed when locutionary act is composed of sounds; phatic acts are performed when locutionary act is expressed in words and rhetic acts are performed when these words are significantly interpreted and explained. Thus, sentences are formed through words appropriate to grammar and language structure. In utterances tebrik ederim and yolunuz açık olsun , all phonetic, phatic and rhetic acts are realized. Because these utterances are composed of certain voices, expressed with words and realized as rhetic acts by achieving their semantic contexts with the speech acts of congratulation (tebrik ederim) and well wishing (yolunuz açık olsun).

Illocutionary act is an act which affects the relationship between the speaker and the receiver. Each locutionary act has a content of illocutionary act. For example, when saying "I need a computer", the speaker expresses his/her desire to buy a computer. And when saying "do you know what time it is?" s/he pushes the receiver to hurry (Kıran \& Kıran, 2013). Illocutionary act include acts realized while performing locutionary acts. The power of illocutionary act emerges while pushing people to do things by language. For example, illocutionary acts are performed such as announcing, asking questions, giving information, ordering, making a request, making appointments (Çelebi, 2014).

Levinson (1992) considers perlocutionary act as effect that is created by speech, and as the part which shows the result or the effect of the speech. Perlocutionary act allows the speaker to effect on the listener. For example, in an electoral speech, a perlocutionary act may provoke enthusiasm, a certain thought, a belief (Kıran \& Kıran, 2013).

From what has been said so far, it can be said on the connection between speech acts and formulaic expressions: locutionary act is a simple grammatical statement, closed to extralinguistic items. In this respect, each formulaic expression can be considered as locutionary act. However, a number of factors, such as context and space, lead formulaic expressions in the form of simple locutionary act to become illocutionary or perlocutionary acts. For example, the formulaic expression günaydın, one of the greeting speech acts and, said in the morning hours, gets rid of temporality and gains a new semantic content with the effect of the context change when it comes to give an ironical reaction to somebody who understands something hardly and lately. In this new context, the formulaic expression günaydın becomes a locutionary act. Because when the listener is told about this formulaic expression, $s /$ he simultaneously understands that $s / h e$ realizes a situation hardly and lately. A speaker performs an illocutionary act when s/he says "I need a computer" to a salesperson at a computer store because $s / h e$ declares directly and simultaneously his/her intent to buy a computer. This illocutionary act becomes a perlocutionary act when the speaker says it to a person who is likely to buy him/her this computer (such as his/her father or boss) because this will influence the person to buy a computer. As can be seen, the basic components of the illocutionary act are simultaneity and directness between speech and act. Perlocutionary act does not have these components. As basic components, perlocutionary acts have duration and indirectness, instead. Duration means time passed between speech and act which is expected to be performed; as the effect is not instantaneous, it is indirect. 


\section{Formulaic Expressions}

Formulaic expressions are stereotypes used in certain situations and times. Turkish is a very rich language in terms of formulaic expressions. There are possible formulaic expressions to be used for almost every situation. These expressions make communication much easier in the language. They prevent word extravagance, are quickly learned and kept in mind. Another reason for the widespread use of formulaic expressions is that they can be told and understood in a short time without much effort in oral and written communication (Wray, 2002). Formulaic expressions are interesting expressions which are stored in the memory of a society and facilitate expression in speech. Especially in speaking, stereotyped units, which were previously stored in memory, can be easily remembered and immediately used by the speakers and quickly understood by the listeners, too (Gökdayı, 2008). It is the shortest, most effective, and linguistic expression of a situation. Whenever a situation arises, it is the case that the expression concerning this situation comes to mind first.

The specific expressions of each society will undoubtedly give clues about the history, culture, structure and life of that society. Turkish formulaic expressions give information about the identity of Turkish society and shed light on its culture. Formulaic expressions seem to show how rich is Turkish. For example, when the formulaic expressions hayırlı olsun, güle güle kullan(ın), iyi günlerde kullan(ın) are told to someone who buys a new item in Turkish society, s/he has to respond by saying daha iyisi senin/sizin olsun, teşekkür ederim or sağ ol(un). As can be seen, the presence, place of use, frequency and variety of formulaic expressions are due to culture. In other words, culture requires the use of these expressions. As previously mentioned, Kula (1996) considers formulaic expressions as culture units since he regards this relationship as very powerful. Culture unit is the place where the culturality of language becomes evident. For example, culture units (formulaic expressions) which are told in case of condolences, birth or separation tell us about the relationship established by individuals belonging to that community.

Proverbs, idioms, reduplications, and compound words as other elements that make up vocabulary, create syntax with at least two words coming in succession whereas formulaic expressions can also be formed in one word. Alo, selam, aferin, yaşasın, tamam, lütfen, etc. are formulaic expressions with one word. Formulaic expressions can be seen with different sentence structures such as Allahın adını verdim (sentence), Allah için (prepositional phrase), rica etsem (optative sentence), selam söyle (imperative sentence), teşekkür ederim (present tense), ucuz atlattık (past tense) etc. In this case, it is seen that formulaic expressions do not only consist of words, but can also appear as a sentence and thus have their syntactic features.

Formulaic expressions are used frequently because they are generally composed of few words and are units that immediately come to mind. Lütfen, merhaba, pardon, peki, buyurun, çok yaşa, sen de gör, kolay gelsin, tebrikler, inşallah, are examples of formulaic expressions with few words. On the other hand, there are also commonly used formulaic expressions in long sentences of 4-10 words. Bir varmış bir yokmuş, evvel zaman içinde kalbur saman içinde, Allah'ın emri peygamberin kavliyle (kızınızı oğlumuza istiyoruz), benim hakkımda ne düşünüyorsan Allah sana $x$ mislini versin, yediğin içtiğin senin olsun gezdiğin gördüğün yerleri anlat, $X$ belediyesinin bana verdiği yetkiye dayanarak siz(ler)i karı koca ilan ediyorum, are examples of sentences frequently used as formulaic expressions with many words.

Based on the above mentioned features, it can be said that the use of formulaic expressions in Turkish requires a certain context, a certain time and a certain place and messages desired to be given in formulaic expressions, quintessentially composed with few words or long sentences in some cases, are fully compatible with the context.

Formulaic expressions are mostly used literally, but there are some expressions that can be misunderstood if perceived in the true sense. In order to prevent such misunderstandings, it is necessary to teach how these expressions are used. Students should be taught that the formulaic expressions such as güle güle kullanın, yerin kulağı var, taş çatlasa and buyurun are not used in the real sense but carry a figurative meaning. Otherwise, very different situations may arise. For example, being said to someone who buys a new item, the expression güle güle kullanın does not mean "use it by laughing". It is a formulaic expression presenting a wish for the person who buys a new item so that $\mathrm{s} /$ he is happy while using it. Yerin kulağı var is also one of the formulaic expression with a figurative meaning. This expression is meant to speak quietly, as it can be heard by someone. Although it means literally command and order, the formulaic expression buyurun is one of the multifunctional expressions that we say to welcome someone coming to a shop or store, to show that we listen to someone who asks something or to allow someone who wants to do something. In some cases, more than one formulaic expression may come to mind simultaneously for some speech acts, but in connection with the situation, the speaker chooses among them the appropriate one. For example, although there are many formulaic expressions used in the context of asking how people are, nasılsın, ne haber, nasıl gidiyor, ne var ne yok, are 
used in informal situations while nasılsınız is employed in formal situations. Among formulaic expressions with similar functions, the appropriate one is selected for the same situation.

The number of works related to formulaic expressions cannot be said sufficient in the literature of Teaching Turkish as a foreign language. There are theoretical studies on formulaic expressions in Turkish, thesis and articles about the reflections of formulaic expressions in Anatolian dialects (Bulut, 2012; Gökdayı, 2011), research articles aiming to examine formulaic expressions in Turkish textbooks which are used in schools (Okuyan, 2012; Canbulat \& Dilekçi, 2013; Bursalı \& Ünal, 2015), articles which analyze formulaic expressions only in one of the textbooks of Turkish as a foreign language (Tüm \& Sarkmaz, 2012; Ünsal, 2013; Tüm \& Uğuz, 2014) but no studies that integrally examine formulaic expressions in textbooks of Turkish as a foreign language have been found. The present study, which aims to address this shortcoming, will seek answers to the following questions:

Based on these problems, the present study seeks answers to the following questions:

1. Which speech acts and formulaic expressions are used in textbooks of Turkish as a foreign language?

2. What is the relationship between formulaic expressions in terms of frequency of use?

3. Do the frequency and variety of the use of formulaic expressions differ in textbooks and workbooks of Turkish as a foreign language?

\section{Method}

\section{Research Design}

The data of the study were collected through document review. Document review covers the analysis of written materials containing information on incidents or facts intended to be investigated (Yıldırım \& Şimşek, 2005).

\section{Criteria of formulaic expression}

Besides the study of Gokdayi (2011), no studies have been found that provide concrete criteria for evaluating any expression as formulaic expression in literature. Gokdayi (2011) presented five criteria for any word to be considered as formulaic expression: structure, meaning, function, context and frequency.

The structure criterion refers to the linguistic phenomenon of stereotypes. For example, the formulaic expression Ayran içtik ayrı (mı) düştük cannot be converted to formats such as Kahve içtik ayrı (mı) düştük or Ayran içtik diye ayrılmayalım; similarly, the formulaic expression Sakalımız yok ki sözümüz dinlensin cannot be converted to a format such as Bıyığımız yok ki sözümüz dinlensin, either. In the present study, if one of the elements of any formulaic expression was removed or replaced by another element, the expression was not considered as formulaic and excluded from the analysis. On the other hand, as in the examples yolun (uz) açık olsun and sağlıcakla kal(In), morphological changes were considered acceptable and included in the analysis.

With the meaning criterion, it is emphasized that formulaic expressions are generally used in their literal meanings, but some expressions are metaphorical, they may create confusion if they are taken with their real meaning, and therefore the meaning in which they are used should be given correctly. For example, her işte bir hayır vardir is one of the formulaic expressions with metaphorical meaning and it should not be taken in its literal meaning by a person who learns Turkish as a foreign language. This expression means that bad events that happen would be auspicious, at that time or later. While teaching this formulaic expression, it should be taught that hayır is not meant to reject but that it is a word that is said to be good, useful and auspicious.

The function criterion indicate that expressions ready to be used are used both quickly and in most appropriate way without any need to produce words by thinking in certain communication situations. For example, when it comes to communicating with someone who has recently lost their relatives, in this difficult situation, the use of formulaic expressions such as Allah rahmet eylesin, nur içinde yatsın, toprağı bol olsun, etc. instead of trying to speak by thinking within the framework of condolence shows this aspect of the function criterion.

The relationship among the context of communication and space and time is expressed with the context criterion. The expression that best suits the situation of communication is selected by this criterion. For example, Allah bir yastıkta kocatsin is not a formulaic expression to be said to singles (situation) and those who have been married for many years (time). It is an expression that is told only to newlyweds.

The frequency is not to be understood as the quantitative use of any formulaic expression. Because not only there may be other stereotypical expressions quantitatively used a lot (e.g. proverbs, idioms, etc.) but also expressions of little use, quantitatively speaking. Thus, frequency should be understood as a) first expressions 
that come to mind in a particular case, b) same expressions coming to mind when the same situation of communication occurs. In case of illness, geçmiş olsun and Allah acil şifalar versin are the first formulaic expressions that come to mind, and these are the expressions which will continue to be mentioned in the recurrence of illness.

The criteria of structure, meaning, function, context, and frequency, presented by Gokdayi (2011), do not seem to be concrete criterion for the selection of formulaic expressions, but rather to provide a better understanding of the nature of these expressions. Because, it is not possible to distinguish formulaic expressions from other stereotypes (proverbs, idioms, reduplications, and compound words) on the basis of these criteria. For example, the formulaic expression elinize sağlık, the proverb bir elin nesi var iki elin sesi var, the idiom el ele vermek and the reduplication el ele in the sentence El ele verip bu işin üstesinden geldiler, the compound words el işi, el yapımı, etc., briefly, the common ground of all these uses are the criteria of structure, meaning, function, context and frequency. Therefore, more criteria are needed. We think that reliable distinction can only be made by adding a criterion which can be called sense of structural-functional familiarity. For example, as Turkish language speakers, we have familiarity with the expression that el ele vermek is not a reduplication but idiom. We also know that el ele vermek will not be a proverb because proverbs are linguistic structures that carry statements, and often with more elements than reduplications, idioms and stereotypes.

\section{Data Collection and Analysis}

The database of the study consists of three textbooks of Turkish as a foreign language: Yeni Hitit, Istanbul, and Izmir.

Speech acts were first determined in all the books and formulaic expressions of these speech acts were classified according to their meanings and contexts. Thus, the frequency and variety of formulaic expressions in the textbooks and workbooks of Turkish as a foreign language was studied.

The data obtained by document analysis were analyzed by content analysis. The fundamental process in content analysis is to bring together similar data within the framework of certain concepts and themes and to interpret them in a way that the reader can understand them (Yıldııım \& Şimşek, 2005). Within the framework of this fundamental objective, main categories and sub-categories should first be determined and defined and context units (word, sentence, paragraph, etc.) should then be selected for the analysis (Yıldırım \& Şimşek, 2005; Balcl, 2009). Accordingly, all books which constitute the corpus were searched unit by unit, from the expressions in these units, the ones that met the criteria of being formulaic expressions were determined as formulaic and others were excluded from the analysis. Formulaic expressions obtained at the end of the survey were classified under the main category of speech acts in terms of their context and semantic content and were prepared for content analysis.

\section{Results}

\section{Speech Acts and Formulaic Expressions}

Three sets of Turkish as foreign language textbooks in the corpus were searched and expressions which met the criteria of being formulaic expressions were determined as formulaic. 193 formulaic expressions meeting these criteria were found in the textbooks and workbooks. These expressions were identified as subcategories linked to 21 speech acts considered as main categories: anger, apologizing, asking a question, asking how someone is, astonishment, attention getting, condolence, congratulating, consent, desire, greeting, invitation, joy, order/request, presentation, rejection, responding, saying goodbye, thanking, welcoming and well wishing. These speech acts are shown in Table 1 . The vertical reading of the table provides information about the numbers of speech acts in the textbooks while the horizontal reading provides comparative information concerning the numbers of speech acts among the textbooks.

The speech acts in the textbooks were analyzed after their use frequencies had been coded as very highly (30 and over), highly (between 10-20), moderately (between 5-10), slightly (between 2-5) and very slightly (use only once). Accordingly, well wishing and responding were used very highly, greeting, saying goodbye, consent, thanking and asking a question highly, asking how someone is, invitation, attention getting, welcoming and astonishment moderately, apologizing, congratulating, order /request and presentation slightly and condolence, anger, desire, rejection and joy very slightly. 
Table 1.

Number of Speech Acts and Formulaic Expressions in the Textbooks of TFL.

\begin{tabular}{llrrrr}
\hline & Speech acts & istanbul A1-A2 & izmir A1-A2 & Yeni Hitit A1-A2 & Total \\
\hline 1 & Well wishing & $13^{*}$ & 11 & 12 & 36 \\
2 & Responding & 12 & 9 & 5 & 33 \\
3 & Greeting & 6 & 6 & 4 & 17 \\
4 & Saying goodbye & 6 & 5 & 4 & 15 \\
5 & Consent & 5 & 5 & 5 & 14 \\
6 & Thanking & 5 & 3 & 4 & 13 \\
7 & Asking a question & 4 & 3 & 4 & 11 \\
8 & Asking how someone is & 3 & 2 & 3 & 9 \\
9 & Invitation & 2 & 2 & 2 & 7 \\
10 & Attention getting & 3 & 1 & 2 & 6 \\
11 & Welcoming & 2 & 2 & 3 & 6 \\
12 & Astonishment & 1 & 2 & 2 & 6 \\
13 & Apologizing & 1 & 1 & 2 & 5 \\
14 & Congratulating & 1 & 1 & 1 & 4 \\
15 & Order /request & 1 & 1 & 3 \\
16 & Presentation & 1 & 0 & 3 \\
17 & Condolence & 1 & 0 & 1 \\
18 & Anger & 0 & 1 & 0 & 1 \\
19 & Desire & 1 & 0 & 0 & 1 \\
20 & Rejection & 0 & 0 & 1 & 1 \\
21 & Joy & 1 & 57 & 0 & 193 \\
\hline
\end{tabular}

* shows the number of formulaic expressions of the well wishing speech act.

A detailed examination of speech acts and formulaic expressions included in the TFL textbooks revealed that Istanbul set had 19 speech acts and 68 formulaic expressions, Izmir set 17 speech acts and 65 formulaic expressions and Yeni Hitit set 17 speech acts and 65 formulaic expressions.

The formulaic expressions of the speech act well wishing afiyet olsun, çok yaşa, geçmiş olsun, hayırlı olsun, iyi yolculuklar and kolay gelsin were used in all the three textbooks; başarılar dilerim, güle güle kullanın/güle güle giyin/ iyi günlerde kullanın in Izmir and Yeni Hitit; hayırlı işler, iyi şanslar in Istanbul and Yeni Hitit. Allah bağışlasın, inşallah, iyi dersler, iyi tatiller and yolunuz açık olsun were preferred only by Istanbul; darısı başına, hayırlısı olsun and iyi çalışmalar only by Izmir; maşallah and şerefe only by Yeni Hitit. The formulaic expressions of the speech act responding güle güle, hoş bulduk, iyilik/iyilik-sağlık, iyiyim, maalesef, memnun oldum and rica ederim were used in all the three textbooks; alo in Izmir and Yeni Hitit; elbette, fena değil and önemli değil in Istanbul and Yeni Hitit. Bir şey değil found place only in Yeni Hitit; eh işte only in Istanbul and sen de gör/hep beraber only in Izmir.

The formulaic expressions of the speech act greeting günaydın, iyi günler, merhaba and selam were employed in all the three textbooks; iyi akşamlar in Istanbul and Yeni Hitit and selam söyle only in Izmir. The formulaic expressions of the speech act saying goodbye görüşmek üzere, görüşürüz, hoşça kal(ın) and iyi günler took place in all the three textbooks; kendine iyi bak in Istanbul and Yeni Hitit; iyi eğlenceler only in Izmir and iyi geceler only in Istanbul. The formulaic expressions of the speech act consent peki, tabi and tamam were used in all the three textbooks; elbette in Izmir and Yeni Hitit; buyur(un) and hay hay only in Izmir and memnuniyetle only in Istanbul. The formulaic expressions of the speech act thanking sağ ol(un), teşekkür ederim and teşekkürler were preferred by all the three textbooks; eline(ize) sağlık by Istanbul and Yeni Hitit and ağzına sağlık only by Istanbul. The formulaic expressions of the speech act asking a question nasıl yardımcı olabilirim/yardımcı olabilir miyim and neyiniz var/şikâyetiniz nedir were used in all the three textbooks; başka bir arzunuz/başka bir şey var mı/başka bir şeye ihtiyacınız var mı and borcum ne kadar in Istanbul and Yeni Hitit and nakit mi kredi kartı mı only in Yeni Hitit.

The formulaic expressions of the speech act asking how someone is nasılsın(Iz) and ne haber took place used in all the three textbooks and ne var ne yok only in Istanbul. Buyur(un) and ha(y)di of the speech act invitation were found in all the three textbooks. The formulaic expression of the speech act attention getting pardon was used in all the three textbooks; affedersiniz in Istanbul and Yeni Hitit and bakar mısın(ız) and özür 
dilerim only in Istanbul. The formulaic expression of the speech act welcoming buyurun and hos geldiniz found place in all the three textbooks. The formulaic expression of the speech act astonishment öyle mi was employed in all the three textbooks; Allah Allah and hay Allah only in Yeni Hitit.

The formulaic expression of the speech act apologizing özür dilerim was used in Izmir and Yeni Hitit; pardon in Istanbul and affedersiniz Izmir and only in Yeni Hitit. The formulaic expression of the speech act congratulating tebrikler was found in all the three textbooks and gözün(üz) aydın and tebrik ederim only in Yeni Hitit. Lütfen of the order/request speech act and buyurun of the presentation speech act were used in all the three textbooks.

Başın(ız) sağ olsun, başka sefere and yaşasıı of the speech acts respectively condolence, desire and joy were found only in Istanbul; Allah Allah of the speech act anger only in Izmir and maalesef of the speech act rejection only in Yeni Hitit.

\section{Frequencies of Speech Acts}

The formulaic expressions were examined in terms of their frequencies and frequencies of the speech acts and formulaic expressions are given in Table 2. The horizontal reading provides comparative information about the frequencies of speech acts among the textbooks while the vertical reading of the table provides information concerning the frequencies of speech acts in the textbooks. In total, 1274 formulaic expressions were found when examined in terms of their frequencies: Istanbul 442, Izmir 429 and Yeni Hitit 403.

Table 2.

Frequencies of Speech Acts and Formulaic Expressions in the Textbooks of TFL.

\begin{tabular}{|c|c|c|c|c|c|}
\hline & Speech acts & İstanbul A1-A2 & İzmir A1-A2 & Yeni Hitit A1-A2 & Total \\
\hline 1 & Well wishing & 90 & 77 & 62 & 229 \\
\hline 2 & Responding & 80 & 80 & 60 & 220 \\
\hline 3 & Saying goodbye & 37 & 62 & 52 & 151 \\
\hline 4 & Greeting & 46 & 36 & 61 & 143 \\
\hline 5 & Consent & 38 & 53 & 26 & 117 \\
\hline 6 & Thanking & 44 & 36 & 31 & 111 \\
\hline 7 & Asking a question & 36 & 23 & 20 & 79 \\
\hline 8 & Invitation & 16 & 9 & 20 & 45 \\
\hline 9 & Asking how someone is & 7 & 16 & 15 & 38 \\
\hline 10 & Welcoming & 8 & 10 & 10 & 28 \\
\hline 11 & Apologizing & 14 & 8 & 6 & 28 \\
\hline 12 & Attention getting & 10 & 7 & 9 & 26 \\
\hline 13 & Astonishment & 4 & 3 & 8 & 15 \\
\hline 14 & Order /request & 1 & 3 & 9 & 13 \\
\hline 15 & Congratulating & 3 & 1 & 7 & 11 \\
\hline 16 & Presentation & 3 & 3 & 4 & 10 \\
\hline 17 & Desire & 0 & 0 & 3 & 3 \\
\hline 18 & Anger & 0 & 2 & 0 & 2 \\
\hline 19 & Joy & 2 & 0 & 0 & 2 \\
\hline 20 & Condolence & 2 & 0 & 0 & 2 \\
\hline \multirow[t]{2}{*}{21} & Rejection & 1 & 0 & 0 & 1 \\
\hline & Total & 442 & 429 & 403 & 1274 \\
\hline
\end{tabular}

When the relationship between the numbers and frequencies of formulaic expressions is examined, it is generally observed that there is a direct proportion between quantity and frequency, in other words, the frequencies of formulaic expressions increase as their numbers increase. However, some of the speech acts had a descent in the order of use frequency since their frequencies were lower than their quantities while some others had an ascent because their frequencies were higher than their quantities. Consequently, the frequencies of the speech acts greeting, asking how someone is, attention getting, astonishment and congratulation were lower than their quantities whereas the frequencies of saying goodbye, invitation, welcoming, apologizing and order/request were higher. 


\section{Formulaic Expressions in the Textbooks and Workbooks}

The textbooks and workbooks were compared in terms of frequency and diversity of use and the results are given in Table 3a and Table 3b. With the data obtained, the third research question was tried to be answered in two stages: whether informational contents related to speech acts and formulaic expressions is transferred from the textbooks into the workbooks (being able to carry informational contents into the workbooks); whether informational contents not presented in the textbooks are included in the exercise books (requesting unpresented informational contents).

Table 3a.

Frequencies of Speech Acts and Formulaic Expressions in the Textbooks and Workbooks of TFL.

\begin{tabular}{|c|c|c|c|c|c|c|c|c|c|c|c|}
\hline Books & 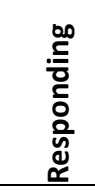 & 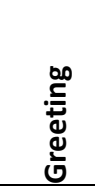 & 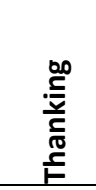 & 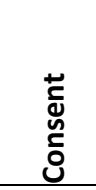 & 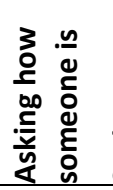 & 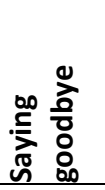 & $\begin{array}{l}\stackrel{\infty}{\frac{5}{5}} \\
\frac{n}{\frac{n}{3}} \\
\frac{\bar{n}}{3} \\
3\end{array}$ & 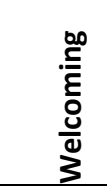 & 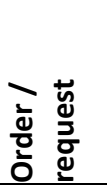 & 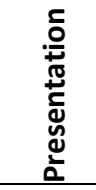 & 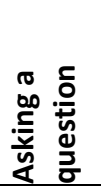 \\
\hline İstanbul Textbook & 67 & 46 & 33 & 26 & 28 & 28 & 30 & 6 & 6 & 4 & 3 \\
\hline İstanbul Workbook & 23 & 34 & 13 & 11 & 10 & 16 & 6 & 1 & 8 & 6 & 5 \\
\hline Total & 90 & 80 & 46 & 37 & 38 & 44 & 36 & 7 & 14 & 10 & 8 \\
\hline $\begin{array}{l}\text { Textbook/Workbook } \\
\text { Difference \% }\end{array}$ & 65.68 & 26.09 & 60.61 & 57.70 & 64.29 & 42.86 & 20.00 & 83.34 & 25.00 & 33.34 & 40.00 \\
\hline İzmir Textbook & 58 & 58 & 27 & 36 & 47 & 25 & 19 & 9 & 8 & 6 & - \\
\hline $\begin{array}{l}\text { İzmir } \\
\text { Workb }\end{array}$ & 19 & 22 & 9 & 26 & 6 & 11 & 4 & 0 & 1 & 1 & 1 \\
\hline Total & 77 & 80 & 36 & 62 & 53 & 36 & 23 & 9 & 9 & 7 & 10 \\
\hline $\begin{array}{l}\text { Textbook/Workbook } \\
\text { Difference \% }\end{array}$ & 67.25 & 62.07 & 66.67 & 27.78 & 87.24 & 56.00 & 78.95 & 100.00 & 87.50 & 83.34 & 88.89 \\
\hline Yeni Hitit Textbook & 38 & 33 & 38 & 31 & 14 & 18 & 9 & 9 & 16 & 4 & 0 \\
\hline Yeni Hitit Workbook & 24 & 27 & 23 & 21 & 12 & 13 & 10 & 6 & 4 & 5 & 2 \\
\hline Total & 62 & 60 & 61 & 52 & 26 & 31 & 19 & 15 & 20 & 9 & 10 \\
\hline $\begin{array}{l}\text { Textbook/Workbook } \\
\text { Difference \% }\end{array}$ & 36.85 & 18.19 & 39.48 & 32.26 & 14.29 & 27.78 & 10.00 & 33.34 & 75.00 & 20.00 & 75.00 \\
\hline
\end{tabular}

\section{Table 3b.}

Frequencies of Speech Acts and Formulaic Expressions in the Textbooks and Workbooks of TFL.

\begin{tabular}{|c|c|c|c|c|c|c|c|c|c|c|}
\hline Books & 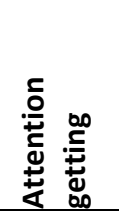 & 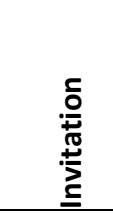 & 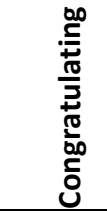 & 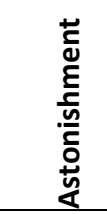 & $\begin{array}{l}\frac{00}{N} \\
\frac{\mathrm{N}}{00} \\
\frac{0}{0} \\
\frac{0}{2}\end{array}$ & 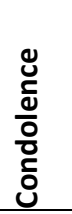 & $\begin{array}{l}\stackrel{ \pm}{\Delta} \\
\frac{5}{\alpha} \\
\end{array}$ & 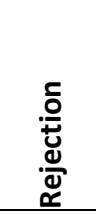 & $\begin{array}{l}\stackrel{\Xi}{\bar{y}} \\
\stackrel{\Delta}{\Delta}\end{array}$ & 호 \\
\hline İstanbul Textbook & 6 & 11 & 3 & 1 & 3 & 1 & 2 & 0 & 1 & 2 \\
\hline İstanbul Workbook & 0 & 3 & 0 & 0 & 0 & 1 & 0 & 0 & 0 & 0 \\
\hline Total & 6 & 14 & 3 & 1 & 3 & 2 & 2 & 0 & 1 & 2 \\
\hline Textbook/Workbook & 100.00 & 72.73 & 100.00 & 100.00 & 100.00 & .00 & 100.00 & .00 & 100.00 & 100.00 \\
\hline \multicolumn{11}{|l|}{ Difference \% } \\
\hline İzmir Textbook & 1 & 8 & 1 & 2 & 2 & 0 & 2 & 0 & 0 & 0 \\
\hline İzmir & 2 & 0 & 0 & 1 & 1 & 0 & 0 & 0 & 0 & 0 \\
\hline \multicolumn{11}{|l|}{ Workbook } \\
\hline Total & 3 & 8 & 1 & 3 & 3 & 0 & 2 & 0 & 0 & 0 \\
\hline Textbook/Workbook & 50.00 & 100.00 & 100.00 & 50.00 & 50.00 & .00 & 100.00 & .00 & .00 & .00 \\
\hline \multicolumn{11}{|l|}{ Difference \% } \\
\hline Yeni Hitit Textbook & 6 & 6 & 4 & 4 & 3 & 0 & 0 & 2 & 0 & 0 \\
\hline Yeni Hitit Workbook & 2 & 0 & 3 & 5 & 1 & 0 & 0 & 1 & 0 & 0 \\
\hline Total & 8 & 6 & 7 & 9 & 4 & 0 & 0 & 3 & 0 & 0 \\
\hline $\begin{array}{l}\text { Textbook/Workbook } \\
\text { Difference \% }\end{array}$ & 66.67 & 100.00 & 25.00 & 20.00 & 66.67 & .00 & .00 & 50.00 & .00 & .00 \\
\hline
\end{tabular}


When examining the transferability of informational contents about speech acts and formulaic expressions from the textbooks into the workbooks, it is seen that Yeni Hitit presented the speech act of invitation (6/0); Izmir the speech acts of welcoming (9/0), invitation (8/0), congratulation (1/0), anger (2/0); Istanbul the speech acts of attention getting (6/0), congratulation (3/0), astonishment $(1 / 0)$, apologizing $(3 / 0)$, anger $(2 / 0)$, desire $(1 / 0)$, joy $(2 / 0)$ in their textbooks but they did not put these speech acts in their workbooks.

In order to compare the sets of Turkish as foreign language textbooks in terms of transferability rate of informational contents from the textbooks into the workbooks, difference of transferability rate for each speech act given in the Table 3 was examined. When fifty percent (half) of difference is determined as base limit, it is found that 11 speech acts in Izmir (asking a question, order/request, asking how someone is, presentation, well wishing, responding, thanking, greeting, saying goodbye, astonishment, apologizing), 6 in Istanbul (welcoming, asking how someone is, thanking, invitation, consent, responding) and 5 in Yeni Hitit (asking a question, order/request, attention getting, apologizing, rejection) were presented with lower frequencies in the workbooks than the textbooks.

When examining Table $3 a$ and $3 b$ in terms of soliciting, in the workbooks, unpresented informational contents about speech acts and formulaic expressions, it is found that none of the unpresented informational contents was requested in the workbooks.

\section{Discussion, Conclusion and Suggestions}

The aim of this study was to compare formulaic expressions in three Turkish as foreign language textbooks. Data obtained to answer to the first research question revealed that speech acts are used in five levels: very highly, highly, moderately, slightly and very slightly. It can be evaluated that the frequency ordering of these speech acts and formulaic expressions reflected from the textbooks does not present a serious contradiction about frequency use of these expressions in daily life. Essential speech acts of daily activities such as greeting, saying goodbye, thanking, asking how someone is seem to take their place in the textbooks with frequencies close to each other.

However, one of the notable findings in the present study is that the speech acts of well wishing and responding were used approximately twice as much as these basic speech acts in the textbooks. Formulaic expressions of giving wishes such as afiyet olsun, geçmiş olsun, hayırlı olsun and kolay gelsin are used in Turkish not only for well wishing but also for greeting and maintaining communication in a sense. The multifunctionality of these expressions can be taught to explain why well wishing is the most used speech act in all the textbooks. As for responding, it seems to be an intersecting speech act which contains in itself several answers for many formulaic expressions. Thus, hoş bulduk responded to the formulaic expression of welcoming hoş geldin(iz); eh işte, fena değil, iyilik/iyilik-sağlık, iyiyim responded to the formulaic expression of asking how someone is nasılsın(ız); güle güle responded to the formulaic expression of saying goodbye hoşça kal(ın) are examples of this situation.

The textbooks seem to approach failure in terms of presenting a balanced representation for some interrelated formulaic expressions. For example, the formulaic expression of responding sen de gör/hep beraber is found only in one textbook although the formulaic expression of well wishing çok yaşa appears in all the three textbooks. The formulaic expression rica ederim to be responded to the formulaic expressions of thanking sağ ol(un), teşekkür ederim, teşekkürler is found in all the three textbooks, önemli değil in two textbooks and bir şey değil in only one textbook. Similarly, while the formulaic expressions of asking how someone is nasılsın(ız) and ne haber are found in all the three textbooks, formulaic expressions iyilik/iyiliksağlık, iyiyim to be positively responded also figure in all the textbooks; fena değil and eh işte to be responded neither positively nor negatively appears respectively in two and one textbooks. Interestingly, the formulaic expressions kötüyüm/iyi değilim/keyifsizim/keyfim yok/tadım yok which will be negatively responded to these questions are not found in any of the textbooks. This lack may be caused by the concern that negative formulaic expressions should be limited while presented to be taught to target language students. The same concern may also explain very slight use of speech acts that require negative formulaic expressions such as anger, rejection and condolence in the textbooks. But, just like formulaic expressions with positive content submitted by speech acts such as well wishing, greeting, thanking, etc. tend to reflect everyday life as it is, speech acts and formulaic expressions of anger, rejection and condolence are indispensable parts of daily life and should be presented and taught as it is.

Although the efforts of the textbooks to reflect speech acts and formulaic expressions from daily life are not considered as unsuccessful in terms of type and quantity, there are some formulaic expressions which are not found in the textbooks although they are frequently used in everyday life. Allaha Ismarladık for the speech act 
of saying goodbye; efendim for responding in telephone; Allah yolunu(zu) açık etsin, Allah zihin açıkığı versin, Allah kolaylık versin; Allah nazardan saklasın, nazar değmesin, Allah saklasın/esirgesin for the speech act of well wishing; daha aşağı olmaz $\mathrm{m}$ ı for the speech act of asking a question in shopping context are some examples. The fact that the formulaic expression of well wishing iyi dersler, that we're used to hearing in school environments, is only found in one textbook and other expressions of this kind, such as başarilar, başarılar diliyorum, are missing, can also be shown as another example of this lack.

With the first research question, which allows to handle speech acts and formulaic expressions regarding type and quantity, these acts and expressions were examined in terms of their relations with each other, especially in relation to their balanced representations. An order of use frequency for these expressions was created based on the first data. By means of the data obtained from the second research question, the formulaic expressions were discussed in terms of their frequency compared to their quantities. In general terms, although there is a direct ratio between high quantity and frequency, a decline was observed in order of use frequency for the speech acts greeting, asking how someone is, attention getting, astonishment and congratulating due to their low frequency compared to their quantity. There is an increase in the speech acts of saying goodbye, invitation, welcoming, apologizing, order/request which have high frequency compared to their quantity. In other words, there are speech acts with low quantity but high frequency of formulaic expressions and speech acts with high quantity but low frequency of formulaic expressions. For the first case, i.e. for low quantity- high frequency, it can be said that reinforcement is stronger than representation while for the second case, i.e. for high quantity-low frequency, representation is stronger than reinforcement. In fact, the textbooks would be stronger in relation to formulaic expressions if both cases, i.e. representation and reinforcement, were given equal importance.

The trace of representation and reinforcement was also driven with data obtained by the third research question. The textbooks were then examined in terms of their ability to carry informational contents related to speech acts and formulaic expressions into the workbooks and whether they request in the workbooks informational contents not included in the textbooks. Apart from a few speech acts, all the three textbooks were able to carry informational contents concerning formulaic expressions into the workbooks. In addition, no textbook put into the workbooks informational contents that are not already presented in the textbooks. With these properties, the sources in the corpus seem to have succeeded in the representation of formulaic expressions in the textbooks and workbooks. However, the same success is far from being in question for reinforcement. Because, only one of the books used half of the speech acts and formulaic expressions in the workbooks while others much less.

The present study revealed that the concepts of representation and reinforcement regarding speech acts and formulaic expressions in the textbooks and workbooks of Turkish as a foreign language. Based on the findings discussed so far, it is possible to underline three results within the framework of these concepts. First, textbooks may have difficulties in providing a balanced representation of interrelated formulaic expressions they contain. Second, although they are frequently used in everyday life, a number of formulaic expressions cannot be included in textbooks, i.e. they cannot be represented. Third, informational contents about speech acts and formulaic expressions in textbooks can be represented being carried into workbooks but they are not reinforced as they are less used in workbooks.

Based on these results, it can be suggested that textbooks to be prepared in the future should take great care to determine and ideally contain formulaic expressions from daily life which are indispensable for linguistic communication. It will also be very important for these expressions to be meticulously represented in textbooks without being overlooked. Again, it would be appropriate for the future textbooks to completely carry into 4workbooks informational contents about speech acts and formulaic expressions and not to request in workbooks informational contents which are not already presented in textbooks. Moreover, a stronger reinforcement of the subject matter would be provided if workbooks in the future contain more formulaic expressions and related exercises than those in textbooks. The present study is limited to three Turkish as foreign language textbooks: Yeni Hitit, Istanbul, and Izmir. Further studies on formulaic expressions would offer more holistic assessments when they add in their corpus more textbooks and workbooks.

\section{Acknowledge}

This paper is extracted from a master thesis "A Comparative Study of Formulaic Expressions in Textbooks of Turkish as a Foreign Language " (2016) submitted by Nahide Arslan to the University of Çukurova 


\section{TÜRKÇE SÜRÜM}

\section{Giriş}

Bir millete ait olan her birey, o milletin kültürünü, dilini, dinini, inançlarını, örf ve adetlerini içinde taşır. Bir bütünün birbirinden ayrılması olanaksız iki parçası olan dil ve kültür eş zamanlı ve birbirleriyle bağlantılı olarak vardırlar. Güvenç (1996)'in de vurguladığı gibi, dili besleyen kültürdür, dilde var olan, kültürde de vardır. Dil, kültürün yansıma ve yaşam alanıdır. Bir toplumun kültürel zenginliği, bilinci, özgünlüğü dilde yankı bulur. Bu nedenle dil, bir toplumun kültürünün, dolayısıyla da yaşam biçiminin en sağlam ve en vazgeçilmez göstergelerinden birisidir.

Dil ve kültür birbirinden ayrı düşünülmediği için birbirini gerekli kılar ve etkileşim içinde kenetlenmiş bir halde bulunur. Bu iki varlık arasındaki ilişki, çeşitli araçlardan yararlanılarak belirginleştirilebilir. iş̧te kalıpsözler ${ }^{1}$, bu araçlardan birisidir. "Tutumumuza ışık tutan dil öğeleri" (Bulut, 2012, p.1118) olan kalıpsözler doğum, evlenme, ölüm gibi insan ve toplum yaşamındaki önemli durumlarda duygu aktarımı ve etkileşim sağlayan dilsel iletişim araçlarıdır (Özdemir 2000).

Her toplumun kendi kültürü içinde, belirli durumlarda söylenmesi adet olmuş belli başlı sözleri vardır. Bu sözler belirli şartlar altında, belirli bir durumda, belirli bir bağlam içerisinde kullanım gerektirir. Vardar (2002) iki tür bağlamdan söz eder: lç bağlam ve dış bağlam. İç bağlam ya da dil içi bağlam "bir dil birimini çevreleyen, ondan önce ya da sonra gelen, birçok durumda söz konusu birimi etkileyen, onun anlamını, değerini belirleyen birim ya da birimler bütünü"'dür (p.30). "Duruma, konuşucu ve dinleyicinin dil dışı toplumsal, ekinsel, ruhsal nitelikli deneyim ve bilgilerine ilişkin verilerin tümü" ise dış bağlam ya da dil dışı bağlam olarak tanımlanır (p.30). Bağlamdan arınık olması düşünülemeyen kalıpsözler, dil içi ve dil dışı bağlamlı kalıpsözler olmak üzere iki şekilde değerlendirilir.

İ̧ bağlama dayalı kalıpsözler konuşma esnasında daha önce söylenmiş bir söze ve onun devamı niteliğinde söylenen sözlere karşılık olabildiği gibi daha sonra iletilecek olan sözlerden ve düşüncelerden önce de kullanılabilir. Olumlu düşünceler, istekler anlamında söylenen (Inşallah, Allah daim etsin, Allah muhtaç etmesin, vb.), kötülükleri defetmek isteyenlerce dile getirilen (Hayrolsun, Allah korusun, Hafazanallah, Allah esirgesin, Maşallah, vb.) ve bazı durumlar karşısında, emin olunamadığında yüce bir güce sığınıp bir şeyler ummak ve olası olumsuzluğun önünü kesmek adına söylenen (Allah büyük, Ağzını hayra aç, Gün doğmadan neler doğar, Allahın dediği olur, vb.) sözler kalıpsöz örnekleri olarak gösterilebilir.

Dil dışı bağlamla ilişkili kalıpsözlerin söylenmesi için ise mutlaka bir durum ya da ortamın oluşması gerekir. Söz gelimi, Türkiye Türkçesinde, Bir yastıkta kocayın kalıpsözü evli çiftlere söylenir, yeni arkadaş olanlara söylenmez. Aksi durumda ilişki kurulamayan anlamsız bir ifadenin ortaya çıkmasına yol açar.

Kalıpsözler, bir topluma ait bireylerin ilişkilerini canlı ve dinamik tutmasını sağlayan iyi düşüncelerin dışa vurulduğu söz ya da sözler dizisidir. Kişilerarası ilişkileri canlı ve sürdürülebilir kılar. Aksan (1996, 2000, 2002, 2003, 2005a, 2005b, 2008), işte tam da bu nedenle kalıpsözleri aynı zamanda ilişki sözleri olarak niteler. Ona göre ilişki sözleri ya da kalıp sözler "her toplumda belli durumlarda söylenmesi gelenek olmuş sözler, duyguları açığa vuran kalıplar, çeşitli basmakalıp sözler"' dir ve bu sözleri tanımlamak ve açıklamak için çoğunlukla dil dışı unsurlardan yararlanılır (2013, p.163). Bilgin (2006) de kalıpsözleri benzer biçimde "belli durumlarda söylenmesi gelenek olmuş sözler" (p.75) biçiminde tanımlar.

Kula (1996), belirli iletişim durumlarında kullanılan iyi dilek, başsağlığı, doğum, ayrılık vb. sözlerin kültür birim (kalıpsöz) olduğunu ve bunların Türk kültürü hakkında bize bilgi verdiğini düşünür. Bu sözler ona göre dilin kültürelliğinin belirginleştiği adlandırmalardır.

Çotuksöken (1994) kalıpsözlerin çoğunlukla dil dışı bağlamlarla oluştuğunu öne sürer. Kalıpsözler "Toplumun bireyleri arasında teşekkür etme, özür dileme, rica etme, tanışma, yolcu karşılama/uğurlama, bir isteği dile getirme gibi çeşitli bağlamlarda kullanılan sözlerdir" (p.28). Kalıpsözler bu bakımdan araştırmacıya göre bağlamsal sözler ya da karşılama sözleri olarak da adlandırılabilir.

\footnotetext{
${ }^{1}$ Kalıpsözler alanyazınında kalıpsöz kavramını kimi araştırmacılar ayrı -kalıp söz-, (Aksan 1996, 2000, 2002, 2003, 2005a, 2005b, 2008; Kula 1996; Ünsal 2013) kimi araştırmacılar ise bitişik -kalıpsöz- yazmayı yeğlemişlerdir (Bilgin 2006; Çotuksöken 1994, 2002). Temel anlamlarını yitirerek bir araya gelen sözcüklerin oluşturduğu birleşik sözcüklerin bitişik yazılması gerektiği kuralından hareketle, kalıpsöz ve sözeylem kavramlarının bitişik yazılması gerektiğini düşünmekteyiz.
} 


\section{Söz Edimleri (Sözeylemler)}

Kalıpsözler, söz varlığında yer alan ve insanın dille gerçekleştirdiğgi iletişimin bir parçasıdır. Kalıpsözler ayrıca günlük dilde, sözlü iletişim esnasında, yazılı metinlerde sıkça kullanılabilen, aynı dili konuşan milletin kültürüyle bezenmiş ve kalıplaşma biçiminde kelime ya da cümle yapısı olabilen birimlerdir. Austin ve Searle, söz edimleri kuramı (speech-acts) çerçevesinde kalıpsöz kavramını dizgeli olarak ele alan ilk araştırmacılar olarak karşımıza çıkmaktadırlar. Söz edimleri kuramı, Austin'in ortaya attığı, öğrencisi Searle tarafından geliştirilmiş bir dil felsefesi kuramıdır. Kalıpsözler ise bir dil felsefesi kuramı olan söz edimi kuramının bir parçası ve insanın dille gerçekleştirdiği iletişimin en küçük birimleridir. Austin (1970)'e göre "söylemek, yapmaktır" (p.15). Yani konuşucu bir şey söylerken aynı zamanda bir edim gerçekleştirir. Böylece dille sağlanan iletişim yalnızca bir bildiriyi iletmekten ibaret değil aynı zamanda edimsel bir işleyişe de sahiptir. Söz edimi kavramında edim, eyleme; söz ise dile gönderme yapmaktadır (Çelebi, 2014).

Austin, söz ile edimin ilişkisi üstüne bu düşünceleri Wittgenstein'in sözün belli bir eylem biçimi olduğunu ve sözcüklerin ya da anlatımların ancak cümlede kullanımlarıyla anlam kazanacağı görüşünden hareketle geliştirmiştir. Herhangi bir sözün anlaşııması için hangi bağlamda kullanıldığının, yerinin, zamanının ve kime söylendiğinin bilinmesi çok önemlidir.

Austin (1970)'e göre üç tür dil edimi vardır: düzsöz, edimsöz ve etkisöz. Düzsöz, dilbilgisi kurallarına uygun, yorumlanmasında ve anlamlandırılmasında dil dışı öğelere gereksinimi olmayan sözlerdir (Vardar, 2002). Edimsöz ve etkisöze gelince, her ikisi de düzsöz üzerine temellenir. Edimsöz, konuşucunun sözü ile sözün içerdiği eylemin aynı anda gerçekleşmesidir. Yani edimsözde söz ile edim eş zamanlıdır (savaş ilanı vb. gibi). Bu durumda söz ile edim arasında bir dolaysızlık da söz konusudur. Etkisözde ise konuşucunun dinleyiciyi dolaylı bir biçimde etkileme niyeti söz konusudur (ikna ve caydırma sözceleri gibi). Yani etkisöz konuşunun niyetine bağlı olarak, alıcı üzerinde etki yapmaya yönelik edimdir (Kıran \& Kıran, 2013).

Düzsöz edimi bir söz üretme edimidir. Sözlüksel, biçimbilimsel ve sözdizimsel görünümdür. Bir şey söylemek, bir söz dağarcığına ait anlamlı birimler üretmek, onları dilbilgisine uygun olarak anlamlı bir sıraya göre yerleştirmektir. Kısacası düzsöz dilbilgisine uygun olarak sözcükler aracilı̆ııla tümceler üretmektir. Austin (1970)'e göre düzsöz edimi ile seslendirme, dillendirme ve anlamlandırma edimleri de gerçekleşmiş olur. Düzsöz ediminin belirli seslerden oluşmasıyla seslendirme edimi, dile ait birtakım sözcüklerle ifade edilmesiyle dillendirme edimi ve bu sözcüklerin anlamlı bir şekilde yorumlanıp açıklanmasıyla da anlamlandırma edimi gerçekleşir. Böylece, dilbilgisine ve dil yapısına uygun sözcükler aracılığıyla tümceler oluşmaktadır. Tebrik ederim ve yolunuz açık olsun sözceleri seslendirme, dillendirme ve anlamlandırma edimlerinin hepsinin birden gerçekleştiği örneklerdir. Zira belirli seslerden oluşan söz konusu sözceler, sözcüklerle anlatım bulmuş, aynı zamanda kutlama (tebrik ederim) ve iyi dilekte bulunma (yolunuz açık olsun) sözeylemleri olarak anlambilimsel bağlamlarına kavuşarak anlamlandırma edimi olmuşlardır.

Edimsöz, konuşucuyla alıcı arasındaki ilişkiyi etkileyen bir olgu niteliğindeki bir sözdür. Her düzsözün bir edimsöz içeriği vardır. Örneğin, "bilgisayara ihtiyacım var" derken, konuşucu bilgisayar satın alma isteğini dile getirir. "Saatin kaç olduğunu biliyor musun?" derken ise alıııı acele etmeye iter (Kıran \& Kıran, 2013). Edimsözler, düzsöz ediminde bulunurken gerçekleştirilen edimleri kapsar. Dil yoluyla kişilere bir iş yaptırılırken edimsöz güçleri ortaya çıkar. Örneğin, bildirimde bulunma, soru sorma, bilgi verme, emretme, rica etme, randevu alma edimsözleri gerçekleşmektedir (Çelebi, 2014).

Levinson (1992), etkisöz edimini, sözün yarattı̆̆ı etki, söz edimin sonucunu ya da etkisini gösteren bölüm olarak değerlendirmektedir. Etkisöz, konuşucunun alıcı üzerinde dolaylı bir etki yapmasını sağlayan sözdür. Örneğin bir seçim söylevinde etkisöz coşkuya, belli bir düşünceye, sava inanmaya yol açabilir (Kıran \& Kıran, 2013).

Şu ana kadar söylenenlerden, söz edimleri kuramı ve kalıpsözleri bağlantııı için şunlar söylenebilir: Düzsöz, dilbilgisi kurallarına uygun, dil dışı öğelere kapalı, sözün taşıdığı yalın bildirimdir. Bu açıdan her kalıpsöz bir düzsöz olarak kabul edilebilir. Bununla birlikte bağlam ve uzam gibi birtakım etkenler yalın düzsöz konumundaki kalıpsözleri edimsöz ya da etkisöz olmaya yöneltir. Örneğin, selamlaşma sözeylemlerinden olan ve sabah saatlerinde söylenen günaydın kalıpsözü, dinleyicinin bir durumu geç kavramasına alaylı tepki vermek söz konusu olduğunda zamansallıktan sıyrılır ve bağlam değişikliğinin etkisiyle yeni bir anlamsal içerik kazanır. Bu yeni bağlamda Günaydın kalıpsözü artık bir edimsöze dönüşmüştür. Zira dinleyici kendisine bu kalıpsöz söylendiğinde eş zamanlı biçimde bir durumu geç kavradığının ayrımına varır. "Bana bilgisayar lazım" düzsözünü dile getiren bir kişi bu sözü bir bilgisayar satış mağazasında satış görevlisine söylediğinde bilgisayar alma niyetini eş zamanlı ve dolaysız dile getireceği için edimsöz; aynı düzsözü kendisine bu bilgisayarı alması olası bir kişinin yanında (babası ya da patronu gibi) söylediğinde söz konusu kişiyi bilgisayar alması yönünde etkileyeceği için etkisöz gerçekleşmiş olur. Görüldüğü üzere edimsözün temel bileşenleri söz ile edim arasındaki eşzamanlılık ve dolaysızlıtır. Etkisözde ise bu özellikler yoktur. Bunlar yerine etkisözün temel bileşenleri olarak süre ve dolaylılık vardır. Süre, söz ile 
gerçekleşmesi beklenen edim arasında geçen belirli bir zamandır; etki anlık olarak ortaya çıkmadığı için doğrudan elde edilmez yani dolaylıdır.

\section{Kalıpsözler}

Kalıpsözler, belli durumlar ve zamanlarda kullanılan basmakalıp sözlerdir. Türkiye Türkçesi kalıpsözler açısından oldukça zengin bir dildir. Neredeyse her durum ve her zaman için kullanılması olanaklı kalıpsözler vardır. Bu sözler dilde iletişimi oldukça kolaylaştırmaktadırlar. Sözcük savurganlığını önlerler, hızlı öğrenilir ve akılda kalııı olurlar. Kalıpsözlerin yaygın kullanılmasının bir başka nedeni sözlü ve yazılı iletişim sırasında çok fazla çaba gerektirmeden kısa zamanda söylenip anlaşılabilmelerindendir (Wray, 2002). Kalıpsözler, toplumun belleğinde duran ve konuşmada anlatımı kolaylaştıran kimi zaman söylenişi renkli sözlerdir. Özellikle konuşma ediminde, daha önceden bir bütün haline getirilip bellekte öylece saklanan kalıplaşmış birimler, konuşanlarca kolaylıkla anımsanıp hemen kullanılabildiği gibi, dinleyici(ler) tarafından da çabucak algılanabilmektedir (Gökdayı, 2008). Uzlaşımsal olarak bir durumun en kısa, en etkili ve dizgeli bir dilsel anlatımıdır. Bir durum her ortaya çıktığında dizgesel bir biçimde o anlatımın ilk akla gelmesi durumudur.

Her toplumun kendine özgü sözleri kuşkusuz o toplumun geçmişi, kültürü, yapısı ve yaşamıyla ilgili ipuçları verir. Türkiye Türkçesinin söz varlığından olan kalıpsözler de, Türk toplumunun kimliği hakkında bilgi verirken diğer yandan kültürüne de ışık tutmaktadır. Kalıpsözler, Türkiye Türkçesinin ne kadar zengin olduğunu gösterir niteliktedir. Söz gelimi, Türk toplumunda yeni bir eşya alan birisine hayırlı olsun, güle güle kullan(ın), iyi günlerde kullan(ın) kalıpsözlerinden biri söylendiği zaman eşya sahibi kişinin de, daha iyisi senin olsun, teşekkür ederim ya da sağ olun demesi gerekir. Görüldüğü üzere, kalıpsözlerin varlığı, kullanım yeri, sıklığı ve çeşitliliği kültürden kaynaklanmaktadır. Başka bir deyişle kültür, bu birimlerin kullanılmasını zorunlu kılmaktadır. Kula (1996) bu ilişkiyi çok güçlü gördüğü için kalıpsözleri, daha öncede değinildiği gibi, kültür birimler olarak kabul etmektedir. Kültür birim dilin kültürelliğinin belirginleştiği yerdir. Örneğin başsağlığı dileme, doğum, ayrılık vb. durumlarda söylenen kültür birimler (kalıpsözler), o topluma ait bireylerin kurdukları ilişki hakkında bize bilgi verir.

Söz varlığını oluşturan diğer öğeler olarak atasözleri, deyimler, ikilemeler ve birleşik sözcüklerin hepsi en az iki sözcüğün art arda gelmesiyle sözdizimi oluştururken kalıpsözler tek kelimeyle de oluşabilmektedirler. Tek sözcüklü olan kalıpsözler: Alo, selam, aferin, yaşasın, tamam, lütfen vb. sözlerdir. Kalıpsözler farklı cümle yapılarıyla da karşımıza çıkabilmektedir. Bunlar: Allahın adını verdim (cümle), Allah için (edat öbeği), rica etsem (istek cümlesi), selam söyle (emir cümlesi), teşekkür ederim (geniş zaman), ucuz atlattık (geçmiş zaman) vb... Bu durumda kalıpsözlerin yalnızca sözcüklerden ibaret olmadığı, cümle olarak karşımıza çıkabileceği ve böylece dizimsel özelliklerinin de olduğu görülmektedir.

Genellikle az sözcükten oluştukları ve akla hemen gelen birimler oldukları için kalıpsözler sık kullanılmaktadır. Söz gelimi, lütfen, merhaba, pardon, peki, buyurun, çok yaşa, sen de gör, kolay gelsin, tebrikler, inşallah, vb. az sözcükten oluşan kalıpsözlere örnektir. Diğer taraftan kullanımı çok yaygın 4-10 sözcükten oluşan uzun cümleler halinde kalıp sözler de vardır. Bir varmış bir yokmuş, evvel zaman içinde kalbur saman içinde, Allah'ın emri peygamberin kavliyle (kızınızı oğlumuza istiyoruz), benim hakkımda ne düşünüyorsan Allah sana $x$ mislini versin, yediğin içtiğin senin olsun gezdiğin gördüğg̈un yerleri anlat, $x$ belediyesinin bana verdiği yetkiye dayanarak siz(ler)i karı koca ilan ediyorum, gibi cümleler yaygın olarak kullanılan ve sözcük sayısının fazla olduğu kalıpsözlerdendir.

Yukarıda sözü edilen özelliklerden yola çıkarak Türkçede yer alan kalıpsözlerin kullanımında belli bir bağlamın, belli bir zamanın ve belli bir yerin olması gerektiğini, özü gereği az sözcükten kimi durumlarda ise uzun cümlelerden oluşabilen kalıpsözlerde verilmek istenen iletinin bağlama tam anlamıyla uygun düştüğü söylenebilir.

Kalıpsözler, çoğunlukla gerçek anlamıyla kullanılır ama bazı kalıpsözler vardır ki gerçek anlamında algılanırsa yanlış anlamalara yol açabilir. İşte bu yanlış anlamayı engellemek için bu sözlerin ne anlamda kullanıldığının öğretilmesi gerekir. Güle güle kullanın, yerin kulağı var, taş çatlasa ve buyurun gibi kalıpsözlerin gerçek anlamda kullanılmadığı asıında mecazi bir anlam taşıdığı bilgisi verilmelidir. Aksi durumda anlatılmak istenenle çok farklı durumlar ortaya çıkabilir. Söz gelimi, yeni bir eşya alan biri için söylenen Güle güle kullanın gülerek kullanmaları anlamına gelmez. Yeni bir eşya alan kişinin söz konusu eşyayı kullandıkça mutlu olması ve memnun kalması anlamında söylenen bir kalıpsözdür. Yerin kulağı var ifadesi yine mecazi bir anlam taşıyan kalıpsözlerden biridir. Bu kalıpsöz, birileri duyabileceği için sessiz konuşulması gerektiği anlamı taşımaktadır. Gerçek anlamı emir ve buyruk anlamına gelse de buyurun kalıpsözü bir mağazaya, dükkâna gelen birini karşılamak, bir şey soran birini dinlediğimizi göstermek ve bir şey yapmak isteyen birine izin verme anlamında söylediğimiz çok işlevli kalıpsözlerden biridir. Bazı durumlarda kimi sözeylemler için birden fazla kalıpsöz eş zamanlı olarak akla gelir 
ama durumla bağlantılı olarak konuşucu bunlardan uygun olanı seçer. Söz gelimi, hal hatır sorma bağlamında kullanılan pek çok kalıpsöz olmasına rağmen resmi olmayan durumlar söz konusu olduğunda nasılsın? ne haber? nasıl gidiyor? ne var ne yok? kullanılırken resmi ve ciddi ortamlarda nasılıınız? kalıpsözünün kullanımı tercih edilmektedir. Aynı durum için benzer işlevli kalıpsözler arasından uygun olanı seçme durumu mevcuttur.

Türkçenin yabancı dil olarak öğretimi alanyazınında kalıpsözler ile ilgili çalışmaların sayısı yeterlidir denilemez. Var olan çalışmalar içerisinde Türkçedeki kalıpsözlerle ilgili kuramsal kitaplar, kalıpsözlerin Anadolu ağızlarındaki yansımalarını incelemeye dönük tez ve makaleler (Bulut, 2012; Gökdayı, 2011), okullardaki Türkçe ders kitaplarında yer alan kalıpsözleri incelemeyi amaçlamış araştırma makaleleri (Okuyan, 2012; Canbulat \& Dilekçi, 2013; Bursalı \& Ünal, 2015), yine yabancılara Türkçe öğretimi ders kitaplarından yalnızca biri içindeki kalıpsözleri inceleme konusu yapan makaleler (Tüm \& Sarkmaz, 2012; Ünsal, 2013; Tüm \& Uğuz, 2014) bulunmakla birlikte yabancılara Türkçe öğretimi ders kitaplarındaki kalıpsözleri bütüncül olarak karşılaştırmalı inceleyen makale ya da tez çalışmasına rastlanamamıştır. Bu eksiği gidermeyi amaçlayan mevcut çalışma aşağıdaki sorulara yanıt arayacaktır:

1. Yabancılara Türkçe öğretimi ders kitaplarında hangi sözeylemler hangi kalıpsözlerle kullanılmaktadır?

2. Kullanım sıklıkları bakımından kalıpsözler arasında nasıl bir ilişki vardır?

3. Kalıpsöz kullanım sıklık ve çeşitlilikleri Türkçe öğretimi ders ve alıştırma kitaplarına göre değişiklik gösteriyor mu?

\section{Yöntem}

\section{Araştırma Modeli}

Araştırmanın verileri doküman incelemesi yoluyla toplanmıştır. Doküman incelemesi, araştırılması amaçlanan olgu ya da olgular hakkında bilgi içeren yazılı materyallerin çözümlemesini kapsar (Yıldırım \& Şimşek, 2005).

\section{Kalıpsöz Olabilme Ölçütleri}

Alanyazında Gökdayı (2011)'nın çalışması dışında, herhangi bir ifadenin kalıpsöz olarak değerlendirilmesini sağlayacak somut ölçütler sunan herhangi bir çalışmaya rastlanamamıştır. Gökdayı (2011), herhangi bir sözün kalıpsöz sayılabilmesi için beş ölçüt sunmuştur: yapı, anlam, işlev, bağlam ve sıklık.

Gökdayı (2011)'nın yapı başlığıyla verdiği ölçüt, kalıplaşma dilsel olgusuna gönderme yapar. Söz gelimi Ayran içtik ayrı (mı) düştük kalıpsözü Kahve içtik ayrı (mı) düştük ya da Ayran içtik diye ayrılmayalım gibi biçimlere ya da Sakalımız yok ki sözümüz dinlensin kalıpsözü Bıyığımız yok ki sözümüz dinlensin gibi biçimlere dönüştürülmez. Mevcut çalışmada donmuş nitelikli kalıpsözlerin öğelerinden biri çıkarılarak ya da bu öğe yerine başka bir öğe kullanıldığında ifade kalıpsöz olarak değerlendirilmemiş ve çözümleme dışı bırakılmıştır. Buna karşılık Yolun(uz) açık olsun ve Sağlıcakla kal(ın) örneklerinde olduğu gibi biçimbilimsel değişiklikler kabul edilebilir değerlendirilmiş ve çözümlemeye katılmıştır.

Anlam ölçütü ile kalıpsözlerin genelde gerçek anlamlarıyla kullanıldıklarını ama bazı kalıpsözlerin mecaz ağırlıklı olduğunu, bunların gerçek anlamlarıyla alınmasının karmaşa yaratacağı, dolayısıyla hangi anlamda kullanıldığının doğru şekilde verilmesi gerektiğini vurgular. Örneğin, her işte bir hayır vardır kalıpsözü mecazi bir anlam taşıyan kalıpsözlerden biri olduğu için Türkçeyi yabancı dil olarak öğrenen bir kişi tarafından gerçek anlamda alınmaması ilkesiyle verilmelidir. Bu kalıpsöz, başa gelen kötü bir olayın ya o an ya da daha sonra farkına varılacak hayırlı şeylere vesile olacağı anlamı taşımaktadır. Söz konusu kalıpsöz öğretilirken hayır kelimesinin reddetme amaçlı söylenen bir söz olmadığı aksine iyi, faydalı ve hayırlı anlamında söylenen bir söz olduğu öğretilmelidir.

Gökdayı (2011) işlev ölçütü ile belirli iletişim durumlarında düşünerek sözce üretmeye gerek kalmadan hâlihazırda, kullanıma hazır bulunan ifadelerin hem hızı hem de duruma en uygun biçimde devreye sokulması durumunu dile getirmektedir. Örneğin, yakınını yeni kaybetmiş birisiyle iletişim kurmak söz konusu olduğunda, bu zor durumda, taziye çerçevesinde düşünerek söz bulmaya çalışmak yerine kullanıma hazır Allah rahmet eylesin, Nur içinde yatsın, Toprağı bol olsun vb. gibi kalıpsözlerin kullanılması işlev ölçütünün bu yönünü göstermektedir.

Bağlam ölçütü ile iletişim durumu, uzam ve zaman arasındaki ilişkiler dile getirilir. İçinde bulunulan iletişim durumuna en uygun olan kalıpsöz bu ölçüt ile seçilir. Örneğin Allah bir yastıkta kocatsın kalıpsözü bekârlara (durum) ve çok uzun yıllardır evli olanlara (zaman) söylenen bir kalıpsöz değildir. Söz konusu kalıpsöz, sadece yeni evlenenlere söylenen bir kalıpsözdür. 
Sıklık herhangi bir kalıpsözün niceliksel olarak çok kullanımı olarak anlaşılmamalıdır. Zira niceliksel olarak çok kullanılan kalıplaşmış başka ifadeler de olabileceği gibi (atasözleri, deyimler vb.) nicel anlamda az kullanılan kalıpsözlerin varlığı da söz konusudur. Böylece sıklık a) belirli bir durumda akla ilk gelen kalıpsöz(ler), b) aynı iletişim durumunun tekrarında akla yine aynı kalıpsöz(ler)'in gelmesi (istikrar) olarak anlaşılmalıdır. Hastalık durumlarında Geçmiş olsun, Allah acil şifalar versin kalıpsözleri akla ilk gelen kalıpsözlerdir ve hastalık durumlarının tekrarlanmasında söylenilmeye devam eden kalıpsözler de yine bunlardır.

Gökdayı (2011)'nın sunduğu yapı, anlam, işlev, bağlam ve sıklık ölçütleri kalıpsözleri ayıklamada somut birer ölçüt olmaktan öte kalıpsözlerin doğasının daha iyi anlaşılmasını sağlamaya dönük bilgiler görünümündedir. Zira kalıpsözleri kalıplaşmış diğer dil birimlerinden (atasözü, deyim, ikileme ve birleşik sözcükler) yalnızca bu ölçütlere dayanarak ayırt edebilmek pek olası görünmemektedir. Söz gelimi, Elinize sağlık kalıpsözü, Bir elin nesi var iki elin sesi var atasözü, El ele verip bu işin üstesinden geldiler tümcesindeki el ele vermek deyimi, el ele ikilemesi ve el işi, el yapımı vb. birleşiklerin ortak paydaları yapı, anlam, işlev, bağlam ve sıklık ölçütleridir. Dolayısıyla bunlardan daha fazla bir ölçüte gerek duyulmaktadır. Sağlıklı ayırımın ancak bu ölçütlere yapısalişlevsel aşinalık duygusu diye adlandırılabilecek bir ölçüt eklenerek yapılabileceği düşüncesindeyiz. Söz gelimi, dil konuşurları olarak el ele vermek anlatımının bir ikileme değil deyim olduğu konusunda aşinalık sahibiyizdir. EI ele vermek anlatımının atasözü olmayacağını da biliyoruz çünkü atasözlerinin yargı taşıyan tümce yapıları ve genellikle ikilemeler, deyimler ve kalıpsözlerden daha fazla öğe barındıran dilsel yapılar olduğunu bilmekteyiz.

\section{Verilerin Toplanması ve Analizi}

Araştırmanın veri tabanını YTÖ’de kullanılan Yeni Hitit, İstanbul, ve İzmir, olmak üzere üç öğretim seti oluşturmaktadır.

Bütünceyi oluşturan tüm kitaplarda ilk olarak sözeylem türleri belirlenmiş, bu sözeylem türlerine ait kalıpsözler anlam ve bağlamlarına göre sınıflandırılmıştır. Böylece Türkiye Türkçesi'nin söz varlığındaki önemli bileşenlerden biri olan kalıpsözlerin YTÖ ders ve alıştırma kitaplarındaki kullanım sıklık ve çeşitlilikleri araştırılmıştır.

Doküman incelemesiyle elde edilen veriler içerik analiziyle çözümlenmiştir. İçerik analizinde temelde yapılan işlem, birbirine benzeyen verileri belirli kavramlar ve izlekler çerçevesinde bir araya getirmek ve bunları okuyucunun anlayabileceği biçimde düzenleyerek yorumlamaktır (Yıldırım \& Şimşek, 2005). Bu temel amaç çerçevesinde öncelikle çözümleme birimi olarak ana ulamlar (kategoriler) ile alt ulamların belirlenip tanımlanması, ardından da çözümlemenin yapılacağı bağlam biriminin (sözcük, tümce, paragraf...) seçilmesi gerekir (Yıldırım \& Şimşek, 2005; Balcı, 2009). Bu doğrultuda, bütünceyi oluşturan kitaplar ünite ünite taranmış, bu ünitelerde yer alan ifadelerden kalıpsöz olma ölçütlerini karşılayanlar kalıpsözler olarak belirlenmiş, diğerleri çözümleme dışında tutulmuştur. Tarama sonunda elde edilen kalıpsözler, anlamsal içerikleri ve bağlamları bakımından sözeylem ana ulamları altında sınıflandırılmış ve içerik çözümlemesine hazır duruma getirilmiştir.

\section{Bulgular}

\section{Sözeylemler ve Kalıpsözleri}

Bütünceyi oluşturan üç Türkçe öğretim seti ünite ünite taranmış ve bu ünitelerde yer alan ifadelerden kalıpsöz olma ölçütlerini karşılayanlar kalıpsözler olarak belirlenmiştir. YTÖ Türkçe ders ve alıştırma kitaplarında kalıpsöz olma ölçütlerini karşılayabilen 193 adet kalıpsöz saptanmıştır. Alt ulamlar olarak belirlenen bu kalıpsözler ana ulam olarak 21 tane sözeyleme bağlanmıştır: cevap verme, davet, dikkat çekme, emir/rica, hal hatır sorma, iyi dilekte bulunma, karşılama, kızma, kutlama, onay, özür dileme, ret, selamlaşma, sevinme, soru sorma, şaşırma, takdim, taziye, temenni, teşekkür etme ve vedalaşma. Söz konusu sözeylemler Tablo 1'de gösterilmiştir. Tablonun dikey okunması, sözeylem türlerinin aynı kitap içerisindeki kalıpsöz miktarları hakkında bilgi verirken, yatay okunması sözeylem ve kalıpsöz miktarlarının kitaplar arası karşılaştırmalı bilgisini sunmaktadır.

Ders kitaplarında sözeylemler toplam kullanım sıklıkları bakımından çok yüksek (30 ve üzeri), yüksek (10-20 arası), orta (5-10 arası), az (2-5 arası) ve çok az (yalnızca bir kez kullanım) biçiminde sınıflandırılarak çözümlenmiştir. Buna göre, İyi dilekte bulunma ve cevap verme çok yüksek, selamlaşma, vedalaşma, onay, teşekkür etme ve soru sorma yüksek, hal hatır sorma, davet, dikkat çekme, karşılama ve şaşırma orta, özür dileme, kutlama, emir-rica ve takdim az, taziye, kızma, temenni, ret ve sevinme ise çok az miktarda kullanılmıştır. 
YTÖ setlerinde hangi sözeylem ve kalıpsözlerin yer aldığı ayrıntılı incelendiğinde İstanbul setinde 19 sözeylem ve bu sözeylemlere ait 68 kalıpsöz; İzmir setinde 16 sözeylem ve 57 kalıpsöz ve Yeni Hitit setinde 17 sözeylem ve 65 kalıpsöz bulgulanmıştır.

Tablo 1.

Türkçe Öğretimi Ders Kitaplarındaki Sözeylemler ve Sözeylemlere ait Kalıpsöz Miktarları.

\begin{tabular}{|c|c|c|c|c|c|}
\hline & Söz eylemler & İstanbul A1-A2 & İzmir A1-A2 & Yeni Hitit A1-A2 & Toplam \\
\hline 1 & İyi dilekte bulunma & $13^{*}$ & 11 & 12 & 36 \\
\hline 2 & Cevap verme & 12 & 9 & 12 & 33 \\
\hline 3 & Selamlaşma & 6 & 6 & 5 & 17 \\
\hline 4 & Vedalaşma & 6 & 5 & 4 & 15 \\
\hline 5 & Onay & 5 & 5 & 4 & 14 \\
\hline 6 & Teşekkür etme & 5 & 3 & 5 & 13 \\
\hline 7 & Soru sorma & 4 & 3 & 4 & 11 \\
\hline 8 & Hal hatır sorma & 3 & 2 & 4 & 9 \\
\hline 9 & Davet & 2 & 2 & 3 & 7 \\
\hline 10 & Dikkat çekme & 3 & 1 & 2 & 6 \\
\hline 11 & Karşılama & 2 & 2 & 2 & 6 \\
\hline 12 & Şaşırma & 1 & 2 & 3 & 6 \\
\hline 13 & Özür dileme & 1 & 2 & 2 & 5 \\
\hline 14 & Kutlama & 1 & 1 & 2 & 4 \\
\hline 15 & Emir /Rica & 1 & 1 & 1 & 3 \\
\hline 16 & Takdim & 1 & 1 & 1 & 3 \\
\hline 17 & Taziye & 1 & 0 & 0 & 1 \\
\hline 18 & Kızma & 0 & 1 & 0 & 1 \\
\hline 19 & Temenni & 1 & 0 & 0 & 1 \\
\hline 20 & Ret & 0 & 0 & 1 & 1 \\
\hline \multirow{2}{*}{21} & Sevinme & 1 & 0 & 0 & 1 \\
\hline & Toplam & 69 & 57 & 67 & 193 \\
\hline
\end{tabular}

*Bu satırda verilen rakamlar iyi dilekte bulunma sözeyleminin kalıpsöz miktarını göstermektedir.

İyi dilekte bulunma sözeylemine ait afiyet olsun, çok yaşa, geçmiş olsun, hayırlı olsun, iyi yolculuklar, kolay gelsin kalıpsözleri her üç kitapta; başarılar dilerim, güle güle kullanın/güle güle giyin/ iyi günlerde kullanın İmir ve Yeni Hitit'te, hayırlı işler, iyi şanslar i̇stanbul ve Yeni Hitit'te kullanılmışlardır. Allah bağışlasın, inşallah, iyi dersler, iyi tatiller ve yolunuz açık olsun yalnızca istanbul'da; darısı başına, hayırlısı olsun ve iyi çalışmalar yalnızca İzmir'de; maşallah ve şerefe de yalnızca Yeni Hitit'te yeğlenmiştir. Cevap verme sözeylemine ait güle güle, hoş bulduk, iyilik/iyilik-sağlık, iyiyim, maalesef, memnun oldum ve rica ederim her üç kitapta; alo İzmir ve Yeni Hitit'te, elbette, fena değil ve önemli değil İstanbul ve Yeni Hitit'te kullanılmışlardır. Bir şey değil yalnızca Yeni Hitit'te; eh işte yalnızca İstanbul'da; sen de gör/hep beraber yalnızca İzmir'de yer bulmuştur.

Selamlaşma sözeylemine ait günaydın, iyi günler, merhaba ve selam kalıpsözleri her üç kitapta; iyi akşamlar İstanbul ve Yeni Hitit'te; selam söyle ise yalnızca İzmir'de kullanılmıştır. Vedalaşma sözeylemi kalıpsözlerinden görüşmek üzere, görüşürüz, hoşça kal(In) ve iyi günler her üç kitapta; kendine iyi bak İstanbul ve Yeni Hitit'te kullanılmıştır. Iyi eğlenceler yalnızca İzmir'de, iyi geceler ise yalnızca İstanbul'da yer almıştır. Onay sözeylemi kalıpsözlerinden peki, tabi ve tamam her üç kitapta; elbette İzmir ve Yeni Hitit'te kullanılmışırı. Buyur(un) ve hay hay yalnızca İzmir'de; memnuniyetle ise yalnızca istanbul'da yer bulmuştur. Teşekkür etme sözeylemine ait sağ ol(un), teşekkür ederim ve teşekkürler kalıpsözleri her üç kitapta; eline(ize) sağlık isstanbul ve Yeni Hitit’te kullanılmıştır. Ağzına sağık ise yalnızca İstanbul'da vardır. Soru sorma sözeylemi kalıpsözlerinden nasıl yardımcı olabilirim/yardımcı olabilir miyim ve neyiniz var/şikâyetiniz nedir her üç kitapta; başka bir arzunuz/başka bir şey var mı/başka bir şeye ihtiyacınız var mı ve borcum ne kadar ìstanbul ve Yeni Hitit'te kullanılmışlardır. Nakit mi kredi kartı mı yalnızca Yeni Hitit'te yer almışır.

Hal hatır sorma sözeylemi kalıpsözlerinden nasılsın(ız), ne haber her üç kitapta, ne var ne yok ise yalnızca İstanbul'da yer almıştır. Davet sözeylemine ait buyur(un) ve ha(y)di üç kitapta da vardır. Dikkat çekme sözeylemi kalıpsözü pardon her üç kitapta; affedersiniz İstanbul ve Yeni Hitit'te kullanılmıştır. Bakar mısın(ız) ve özür dilerim ise yalnızca istanbul'da yer bulmuştur. Karşılama sözeylemi kalıpsözleri olan buyurun ve hoş geldiniz üç kitapta da kullanılmışlardır. Şaşırma sözeylemi kalıpsözü öyle mi üç kitapta da yer almış, Allah Allah ve hay Allah ise yalnızca Yeni Hitit'te kullanılmıştır. 
Özür dileme sözeylemi kalıpsözü özür dilerim İzmir ve Yeni Hitit'te, pardon da istanbul ve i̇zmir'de kullanılmışır. Affedersiniz ise yalnızca Yeni Hitit'te yer bulmuştur. Kutlama sözeylemi kalıpsözlerinden tebrikler her üç kitapta, gözün(üz) aydın ve tebrik ederim ise yalnızca Yeni Hitit’te kullanılmıştır. Emir-rica sözeylemi kalıpsözü lütfen üç kitapta da kullanılmıştır. Takdim sözeylemine ait kalıpsöz buyurun yine her üç kitapta da yer almıştır.

Taziye, temenni ve sevinme sözeylemleri kalıpsözleri olan, sırasıyla, başın(ız) sağ olsun, başka sefere ve yaşasın yalnızca İstanbul'da; kızma sözeylemine ait Allah Allah kalıpsözü yalnızca İzmir'de; ret sözeylemi kalıpsözlerinden maalesef ise yalnızca Yeni Hitit’te kullanılmışlardır.

\section{Kalıpsöz Sıklıkları}

Kalıpsözler, sıklıkları bakımından incelenmiş ve sözeylem türleri ile sözeylemlere ait kalıpsöz sıklıkları Tablo 2'de verilmiştir. Tablonun yatay okunması sözeylemlerin kitaplar arası kalıpsöz sıklıklarını; dikey okunması da aynı kitapta sözeylemler arası kalıpsöz sıklıklarını göstermektedir. Sözeylemler kalıpsöz türlerinin sıklıklarına göre incelendiğinde toplam 1274 kullanım bulunmuştur. İnceleme sonucunda İstanbul'un 442, Izzmir' in 429 ve Yeni Hitit' in 403 kalıpsöz kullandığı görülmüştür.

Tablo 2.

Türkçe Öğretimi Ders Kitaplarındaki Sözeylemler ve Sözeylemlere ait Kalıpsöz Sıklıkları.

\begin{tabular}{|c|c|c|c|c|c|}
\hline & Söz eylemler & İstanbul A1-A2 & İzmir A1-A2 & Yeni Hitit A1-A2 & Toplam \\
\hline 1 & İyi dilekte bulunma & 90 & 77 & 62 & 229 \\
\hline 2 & Cevap verme & 80 & 80 & 60 & 220 \\
\hline 3 & Vedalaşma & 37 & 62 & 52 & 151 \\
\hline 4 & Selamlaşma & 46 & 36 & 61 & 143 \\
\hline 5 & Onay & 38 & 53 & 26 & 117 \\
\hline 6 & Teşekkür etme & 44 & 36 & 31 & 111 \\
\hline 7 & Soru sorma & 36 & 23 & 20 & 79 \\
\hline 8 & Davet & 16 & 9 & 20 & 45 \\
\hline 9 & Hal hatır sorma & 7 & 16 & 15 & 38 \\
\hline 10 & Karşılama & 8 & 10 & 10 & 28 \\
\hline 11 & Özür dileme & 14 & 8 & 6 & 28 \\
\hline 12 & Dikkat çekme & 10 & 7 & 9 & 26 \\
\hline 13 & Şaşırma & 4 & 3 & 8 & 15 \\
\hline 14 & Emir /Rica & 1 & 3 & 9 & 13 \\
\hline 15 & Kutlama & 3 & 1 & 7 & 11 \\
\hline 16 & Takdim & 3 & 3 & 4 & 10 \\
\hline 17 & Temenni & 0 & 0 & 3 & 3 \\
\hline 18 & Kızma & 0 & 2 & 0 & 2 \\
\hline 19 & Sevinme & 2 & 0 & 0 & 2 \\
\hline 20 & Taziye & 2 & 0 & 0 & 2 \\
\hline \multirow[t]{2}{*}{21} & Ret & 1 & 0 & 0 & 1 \\
\hline & Toplam & 442 & 429 & 403 & 1274 \\
\hline
\end{tabular}

Kalıpsöz miktarları ile kalıpsöz sıklıkları arasında nasıl bir ilişki olduğu incelendiğinde, genel olarak, miktar yüksekliği ile sıklık arasında doğru orantı olduğu, diğer bir deyişle, sözeylemlere ait kalıpsöz miktarları arttıkça kalıpsöz sıklıklarııın da arttığı gözlenmektedir. Buna karşın, miktarlarına oranla sıklıkları daha düşük olduğu için bazı sözeylemlerin sıralamadaki yerleri aşağıya doğru, miktarlarına oranla sıklıkları daha yüksek olduğu için de bazı sözeylemlerin sıralamadaki yerleri yukarıya doğru az da olsa değişmiştir. Buna göre, selamlaşma, hal hatır sorma, dikkat çekme, şaşırma, kutlama sözeylemlerinin miktarlarına oranla sıklıkları daha düşük, vedalaşma, davet, karşılama, özür dileme, emir-rica sözeylemlerinin sıklıkları ise miktarlarına oranla daha yüksektir.

\section{Ders ve Alıştırma Kitaplarında Kalıpsözler}

Ders ve alıştırma kitapları kullanım sıklık ve çeşitlilikleri bakımından karşılaştııımış, sonuçlar Tablo 3a ve $3 b^{\prime}$ 'de verilmiştir. Elde edilen verilerle üçüncü araştırma sorusuna iki düzlemde yanıt verilmeye çalışılmıştır: kalıpsözler ve ait oldukları sözeylemler ile ilgili bilgisel içeriklerin ders kitaplarından alıştırma kitaplarına aktarılıp 
aktarılmadığı (bilgisel içerileri alıştırma kitaplarına taşıyabilme); ders kitaplarında sunulmayan bilgisel içeriklerin alışırma kitaplarında yer alıp almadığı (sunulmayan bilgisel içeriği isteme).

Tablo 3a.

Türkçe Öğretimi Ders ve Alıştırma Kitaplarında Sözeylemlere ait Kalıpsöz Sıklıkları.

\begin{tabular}{|c|c|c|c|c|c|c|c|c|c|c|c|}
\hline Kitaplar & 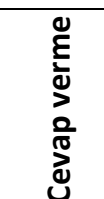 & 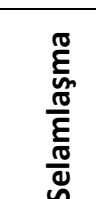 & 窝 & $\underset{0}{\stackrel{\pi}{0}}$ & 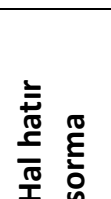 & 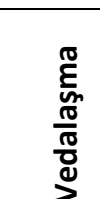 & 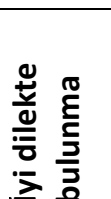 & 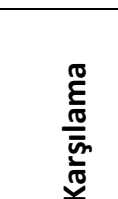 & 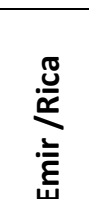 & $\frac{\xi \xi}{\frac{\xi}{\sigma}}$ & 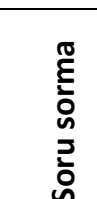 \\
\hline İstanbul Ders Kitabı & 67 & 46 & 33 & 26 & 28 & 28 & 30 & 6 & 6 & 4 & 3 \\
\hline İstanbul Alıştırma Kitabı & 23 & 34 & 13 & 11 & 10 & 16 & 6 & 1 & 8 & 6 & 5 \\
\hline Toplam & 90 & 80 & 46 & 37 & 38 & 44 & 36 & 7 & 14 & 10 & 8 \\
\hline $\begin{array}{l}\text { Ders K./Alıştırma K. Fark } \\
\%\end{array}$ & 65.68 & 26.09 & 60.61 & 57.70 & 64.29 & 42.86 & 20.00 & 83.34 & 25.00 & 33.34 & 40.00 \\
\hline İzmir Ders Kitabı & 58 & 58 & 27 & 36 & 47 & 25 & 19 & 9 & 8 & 6 & 9 \\
\hline İzmir Alıştırma Kitabı & 19 & 22 & 9 & 26 & 6 & 11 & 4 & 0 & 1 & 1 & 1 \\
\hline Toplam & 77 & 80 & 36 & 62 & 53 & 36 & 23 & 9 & 9 & 7 & 10 \\
\hline $\begin{array}{l}\text { Ders K./Alıştırma K. Fark } \\
\%\end{array}$ & 67.25 & 62.07 & 66.67 & 27.78 & 87.24 & 56.00 & 78.95 & 100.00 & 87.50 & 83.34 & 88.89 \\
\hline Yeni Hitit Ders Kitabı & 38 & 33 & 38 & 31 & 14 & 18 & 9 & 9 & 16 & 4 & 8 \\
\hline $\begin{array}{l}\text { Yeni Hitit Alıştırma } \\
\text { Kitabı }\end{array}$ & 24 & 27 & 23 & 21 & 12 & 13 & 10 & 6 & 4 & 5 & 2 \\
\hline Toplam & 62 & 60 & 61 & 52 & 26 & 31 & 19 & 15 & 20 & 9 & 10 \\
\hline $\begin{array}{l}\text { Ders K./Alıştırma K. Fark } \\
\%\end{array}$ & 36.85 & 18.19 & 39.48 & 32.26 & 14.29 & 27.78 & 10.00 & 33.34 & 75.00 & 20.00 & 75.00 \\
\hline
\end{tabular}

Tablo 3b.

Türkçe Öğretimi Ders ve Alıştırma Kitaplarında Sözeylemlere ait Kalıpsöz Sıklıkları.

\begin{tabular}{|c|c|c|c|c|c|c|c|c|c|c|}
\hline Books & 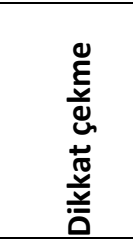 & 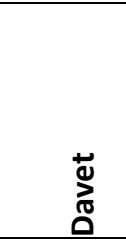 & 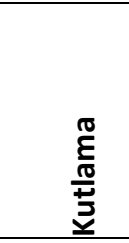 & 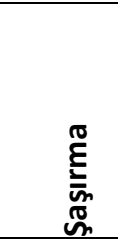 & 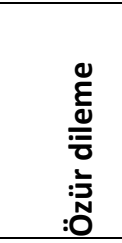 & 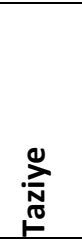 & $\underset{\substack{\tilde{N} \\
\underline{\underline{N}}}}{\underline{\underline{T}}}$ & $\underset{\mathscr{\varpi}}{\ddot{q}}$ & 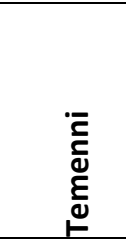 & 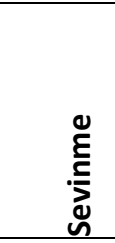 \\
\hline İstanbul Textbook & 6 & 11 & 3 & 1 & 3 & 1 & 2 & 0 & 1 & 2 \\
\hline İstanbul Workbook & 0 & 3 & 0 & 0 & 0 & 1 & 0 & 0 & 0 & 0 \\
\hline Total & 6 & 14 & 3 & 1 & 3 & 2 & 2 & 0 & 1 & 2 \\
\hline $\begin{array}{l}\text { Textbook/Workbook } \\
\text { Difference \% }\end{array}$ & 100.00 & 72.73 & 100.00 & 100.00 & 100.00 & .00 & 100.00 & .00 & 100.00 & 100.00 \\
\hline İzmir Textbook & 1 & 8 & 1 & 2 & 2 & 0 & 2 & 0 & 0 & 0 \\
\hline $\begin{array}{l}\text { İzmir } \\
\text { Workbook }\end{array}$ & 2 & 0 & 0 & 1 & 1 & 0 & 0 & 0 & 0 & 0 \\
\hline Total & 3 & 8 & 1 & 3 & 3 & 0 & 2 & 0 & 0 & 0 \\
\hline $\begin{array}{l}\text { Textbook/Workbook } \\
\text { Difference \% }\end{array}$ & 50.00 & 100.00 & 100.00 & 50.00 & 50.00 & .00 & 100.00 & .00 & .00 & .00 \\
\hline Yeni Hitit Textbook & 6 & 6 & 4 & 4 & 3 & 0 & 0 & 2 & 0 & 0 \\
\hline Yeni Hitit Workbook & 2 & 0 & 3 & 5 & 1 & 0 & 0 & 1 & 0 & 0 \\
\hline Total & 8 & 6 & 7 & 9 & 4 & 0 & 0 & 3 & 0 & 0 \\
\hline $\begin{array}{l}\text { Textbook/Workbook } \\
\text { Difference \% }\end{array}$ & 66.67 & 100.00 & 25.00 & 20.00 & 66.67 & .00 & .00 & 50.00 & .00 & .00 \\
\hline
\end{tabular}


Ders kitaplarındaki kalıpsözler ve ait oldukları sözeylemler ile ilgili bilgisel içeriklerin alıştırma kitaplarına aktarılma durumları incelendiğinde, Yeni Hitit'in yalnızca davet (6/0), İzmir'in; karşılama (9/0), davet (8/0), kutlama (1/0), kızma (2/0) olmak üzere dört, İstanbul'un; dikkat çekme (6/0), kutlama (3/0), şaşırma (1/0), özür dileme (3/0), kızma (2/0), temenni (1/0), sevinme (2/0) olmak üzere yedi sözeylemi ders kitaplarında sunduğu ancak bunlara alıştırma kitaplarında yer vermediği görülmektedir. YTÖ setlerini ders kitaplarında sunulan içeriklerin alıştırma kitaplarına aktarılma oranları bakımından karşılaştırmak amacıyla, Tablo 3'teki her bir sözeylem için verilen aktarılma oran farkları incelenmiştir. Yüzde elli (yarı yarıya) fark çıkan sözeylemler taban sınır olarak belirlendiğinde, İzmir'de on bir (soru sorma, emir/rica, hal hatır sorma, takdim, iyi dilekte bulunma, cevap verme, teşekkür etme, selamlaşma, vedalaşma, şaşırma, özür dileme), ístanbul'da altı (karşılama, hal hatır sorma, teşekkür etme, davet, onay, cevap verme) ve Yeni Hitit'te beş (emir/rica, soru sorma, dikkat çekme, özür dileme, ret) sözeylemin ders kitaplarına oranla alıştırma kitaplarında düşük sıklıkla sunulduğu bulgulanmıştır.

Tablo 3a ve 3b, ders kitaplarında sunulmayan sözeylemler ve içerdikleri kalıpsözlere ilişkin bilgisel içeriklerin alıştırma kitaplarına taşınıp taşınmadığını bağlamında incelendiğinde, sunulmayan hiçbir bilgisel içeriğin alıştırma kitaplarında yer almadığı görülmektedir.

\section{Tartışma, Sonuç ve Öneriler}

Bu çalışma yabancılara Türkçe öğretmekte kullanılan Türkçe öğretim setlerindeki kalıpsözleri birbirleriyle bütünlüklü olarak karşılaştırmayı amaçlamıştır. Birinci araştırma sorusuna yanıt için elde edilen veriler, kalıpsöz miktarları bakımından, sözeylemlerin çok yüksek, yüksek, orta, düşük ve çok düşük oranlarda kullanıldığını ortaya koymuştur. YTÖ kitaplarından yansıyan sözeylemler ve kalıpsözleri ile ilgili bu sıklık sıralamasının söz konusu kalıpsözlerin gündelik yaşamdaki başvuru sıklıkları ile düşünüldüğünde, gündelik yaşamdaki kullanımlara ciddi bir aykırılık sunmadığı değerlendirilebilir. Selamlaşma, vedalaşma, teşekkür etme, hal hatır sorma gibi gündelik yaşamın olmazsa olmaz edimlerine ait sözeylemler birbirine yakın sıklıklarla ders kitaplarında yerlerini almış görünmektedirler.

Buna karşın, mevcut çalışmada dikkat çeken bulgulardan bir tanesi, iyi dilekte bulunma ve cevap verme sözeylemlerinin sözü edilen bu temel edimlere ait kalıpsöz miktarlarından ders kitaplarında yaklaşık iki kat fazla yer almış olmasıdır. Afiyet olsun, geçmiş olsun, hayırı olsun ve kolay gelsin gibi iyi dilek aktaran kalıpsözlerin iyilik dileme özellikleri yanında bir bakıma, selamlama ve iletişimi sürdürme işlevleriyle de kullanılıyor olmaları iyi dilekte bulunma'nın tüm kitaplarda neden en çok kullanılan sözeylem türü olduğunu açıklamaya yardımcı olacağı düşünülebilir. Cevap verme sözeylemi ise birçok sözeylem türü kalıpsözüne yanıt barındıran, kavşak niteliğinde bir sözeylem görünümündedir. Nitekim karşılama sözeylemi kalıpsözü olan hoş geldin(iz)'e verilen hoş bulduk; hal hatır sorma sözeylemi kalıpsözü olan nasılsın(ız)'a verilen eh işte, fena değil, iyilik/iyilik-sağlık, iyiyim; vedalaşma sözeylemi kalıpsözü olan hoşça kal(ın)'a verilen güle güle kalıpsözleri bu durumu örnekler niteliktedir.

Bulgular dikkatle incelendiğinde, ders kitaplarının birbirleriyle bağlantılı bazı kalıpsözler için dengeli temsil sunmakta başarısızlığa yaklaştıkları görülmektedir. Örneğin, iyi dilekte bulunma sözeylemine ait olan çok yaşa kalıpsözü her üç kitapta da yer alırken bu kalıpsöze yanıt niteliğinde olan cevap verme sözeylemine ait sen de gör/hep beraber kalıpsözü yalnızca bir kitapta bulunmaktadır. Teşekkür etme sözeylemi kalıpsözlerinden olan sağ ol(un), teşekkür ederim, teşekkürler kalıpsözlerine cevap olarak rica ederim her üç kitapta bulunurken önemli değil iki kitapta, bir şey değil ise yalnızca tek kitapta yer almaktadır. Benzer biçimde, hal hatır sorma sözeylemi kalıpsözleri olan nasılsın(ız) ve ne haber tüm kitaplarda varken bu kalıpsözlere olumlu yanıt olarak verilen iyilik/iyilik-sağlık, iyiyim tüm kitaplarda, ne olumlu ne olumsuz yanıt niteliğindeki fena değil iki kitapta, eh işte de tek kitapta yer almaktadır. İlginç biçimde, bu soruların olumsuz yanıtı olabilecek kötüyüm/iyi değilim/keyifsizim/keyfim yok/tadım yok vb. kalıpsözleri bütüncedeki hiçbir kitapta bulunmamaktadır. Bu yokluğa hedef dil öğrencilerine olumsuzluk yüklü kalıpsöz aktarımını sınırlandırmak kaygısı neden olmuş olabilir. Aynı kaygı kızma, ret ve taziye gibi olumsuz nitelikli kalıpsözler gerektiren sözeylemlerin ders kitaplarında çok düşük miktarlarda kullanılmasını da açıklayabilir. Oysaki iyi dilekte bulunma, selamlaşma, teşekkür etme vb. sözeylemlerle sunulan olumlu içerikli kalıpsözler nasıl gündelik yaşamı olduğu gibi yansıtmaya yöneliyorsa aynı biçimde kızma, ret ve taziye sözeylem ve kalıpsözleri de bu yaşamın olmazsa olmaz parçalarıdır.

Ders kitaplarının gündelik yaşamdaki sözeylemler ve bunlara ait kalıpsözleri tür ve miktar bağlamında yansıtma çabaları başarısız sayılamasa da gündelik yaşamda sık kullanılmasına karşın ders kitaplarında bulunmayan bir takım kalıpsözler söz konusudur. Vedalaşma sözeylemi içerisindeki Allaha ısmarladık; telefona cevap verme bağlamındaki efendim; iyi dilekte bulunma sözeylemi kapsamında Allah yolunu(zu) açık etsin, Allah zihin açıklığı versin, Allah kolaylık versin; Allah nazardan saklasın, nazar değmesin, Allah 
saklasın/esirgesin; alışveriş bağlamında soru sorma sözeylemi kapsamındaki daha aşağı olmaz mı gibi kalıpsözler bunlardan bazılarıdır. Gündelik yaşamda eğitim-öğretim ortamlarında duymaya alışık olduğumuz iyi dilekte bulunma sözeylemi kalıpsözü iyi derslerin yalnızca bir kitapta bulunması, başarılar, başarılar diliyorum gibi başka kalıpsözlerin yokluğu da bu duruma örnek gösterilebilir.

Sözeylemler ve kalıpsözlerin tür ve miktar düzleminde ele alınmasına olanak sunan birinci araştırma sorusuyla söz konusu sözeylemler ve kalıpsözler birbirleriyle ilişkileri, özellikle de dengeli temsilleri bakımından incelenmiş, ilk verilerle miktarlar üzerinden bir kullanım sıklığı sıralaması oluşturulmuştu. İkinci araştırma sorusuyla elde edilen veriler yoluyla da kalıpsözler, miktarlarına oranla sıklıkları bağlamında ele alınmıştır. Genel anlamda miktar yüksekliği ile sıklık arasında bir doğru orantı gözlemlense de miktarlarına oranla sıklıklarının düşük olması dolayısıyla selamlaşma, hal hatır sorma, dikkat çekme, şaşırma ve kutlama sözeylemlerinde kullanım sıklığı sıralamasında iniş gözlemlenmiştir. Sıklıkları miktarlarına oranla daha yüksek olan vedalaşma, davet, karşılama, özür dileme, emir-rica sözeylemlerinde ise yükseliş söz konusudur. Yani kalıpsöz miktarı düşük, kullanım sıklığı yüksek sözeylemler ve kalıpsöz miktarı yüksek, kullanım sıklığı düşük sözeylemler söz konusudur. illk durum, yani düşük miktar-yüksek sıklık için, pekiştirme temsilden daha güçlü; ikinci durum, yani yüksek miktar-düşük sıklık için de temsil pekiştirmeden güçlü denebilir. Aslında her iki durumunun, hem temsil hem de pekiştirmenin, birlikte önemsenmesi ders kitaplarını kalıpsözler yönünden daha güçlü kılabilirdi.

Temsil ve pekiştirmenin izi üçüncü araştırma sorusuyla elde edilen verilerle de sürülmüştür. Ders kitapları bu kez, kalıpsözler ve ait oldukları sözeylemler ile ilgili bilgisel içerileri alıştırma kitaplarına taşıyabilme ve ders kitaplarında sunulmayan bilgisel içeriği alıştırma kitaplarında isteme durumları bakımından incelenmiştir. Birkaç sözeylem dışında, her üç ders kitabı da kalıpsözlerle ilgili bilgi içeriğini alıştırma kitaplarına taşıyabilmiştir. Ayrıca hiçbir kitap sunulmayan hiçbir bilgisel içeriği alıştırma kitaplarına almamıştır. Bu özellikleriyle bütüncedeki kaynaklar, ders ve alıştırma kitaplarındaki kalıpsözlerin temsil işlemini başarmış görünmektedirler. Ancak aynı başarı, pekiştirme işleminde söz konusu olmaktan uzak gibidir. Zira kitaplardan yalnızca bir tanesi sunduğu sözeylemler ve kalıpsözlerin yarısını, diğerleri ise çok daha azını alıştırma kitaplarında ders kitaplarına oranla daha fazla kullanmıştır.

Mevcut çalışma, YTÖ ders ve alıştırma kitaplarındaki sözeylemler ve kalıpsözlerle bağlantılı olarak temsil ve pekiştirme kavramlarının önemli olduğunu göstermiştir. Şu ana kadar tartışılan bulgulardan hareketle bu kavramlar çerçevesinde üç sonucun altını çizmek olanaklıdır. Birincisi, ders kitaplarının, bünyelerinde barındırdıkları, birbirleriyle bağlantılı kalıpsözleri dengeli bir temsil ile sunmada zorlanabildikleridir. İkincisi, gündelik yaşamda sık kullanılmalarına karşın bir takım kalıpsözlerin ders kitaplarında yerlerini alamadıkları, yani temsil edilemedikleridir. Üçüncüsü, ders kitaplarındaki sözeylemler ve kalıpsözler ile ilgili bilgisel içeriklerin alıştırma kitaplarına taşınarak temsil edilebildiği ancak alıştırma kitaplarında daha az kullanılarak güçlü pekiştirme yoluna girilemediğidir.

Bu sonuçlardan yola çıkarak, ileride hazırlanacak YTÖ ders kitaplarının gündelik yaşamda dilsel iletişimin vazgeçilmezi olan kalıpsözleri belirlemede ve bunları bünyelerine taşımada yüksek titizlik göstermeleri önerilebilir. Titizlikle belirlenecek bu kalıpsözlerin ders kitaplarında birbirleriyle bağlantıları gözden kaçırılmadan temsil edilmeleri de oldukça önemli olacaktır. Yine, gelecekte hazırlanacak YTÖ ders kitaplarının kalıpsözlerle ilgili bilgisel içerikleri alıştırma kitaplarına eksiksiz taşıyabilmesi ve ders kitaplarında sunulmayan bilgisel içerikleri alıştırma kitaplarında istememeleri yerinde olacaktır. Ayrıca, geleceğin YTÖ setlerindeki alıştırma kitaplarının ders kitaplarındakilerden daha fazla kalıpsöz ve bağlantılı alıştırma içermesi kalıpsözler konusunun daha güçlü pekiştirilmesine olanak sunabilir. Mevcut çalışma İstanbul, İzmir ve Yeni Hitit yabancılar için Türkçe öğretim setleriyle sınırlıdır. Kalıpsözler konusunda gelecekte yürütülecek çalışmaların, bütüncelerine daha fazla sayıda YTÖ ders ve alıştırma kitapları eklemeleri daha bütüncül değerlendirmeler sunacaktır.

\section{Bilgilendirme}

Bu çalışma Dr. Öğr. Üyesi Mustafa Mavaşoğlu danışmanlığında Nahide Arslan tarafından hazırlanan "Yabancılara Türkçe Öğretimi Ders Kitaplarındaki Kalıpsözlerin Karşılaştırmalı İncelenmesi “ (2016) başlıklı yüksek lisans tezinden üretilmiştir. 


\section{Kaynakça}

Aksan, D. (1996). Türkçenin sözvarlığı. Ankara: Engin Yayınevi.

Aksan, D. (2000). Türkçenin sözvarlı̆ıı. Ankara: Engin Yayınevi.

Aksan, D. (2002). Anadilimizin söz denizinde. Ankara: Bilgi Yayınevi.

Aksan, D. (2003). Dil, şu büyülü düzen... Ankara: Bilgi Yayınevi.

Aksan, D. (2005a). Türkçenin gücü. Ankara: Bilgi Yayınevi.

Aksan, D. (2005b). Türkşenin zenginlikleri, incelikleri. Ankara: Bilgi Yayınevi.

Aksan, D. (2008).Türkçeye yansıyan Türk kültürü. Ankara: Bilgi Yayınevi.

Aksan, D. (2013). Türkşenin gücü. Ankara: Bilgi Yayınevi.

Austin, J. L. ( 1970 ). Quand dire, c'est faire. (Trans. G. Lane). Paris: Editions du Seuil.

Balcı, A. (2009). Sosyal bilimlerde araştırma. Ankara: Pegem Akademi.

Bilgin, M. (2006). Anlamdan anlatıma Türkçemiz. Ankara: Anı Yayıncılık.

Bölükbaş, F., Gedik, E., Gönültaş, G., Keskin, F., Özenç, F. et al. (2013). Istanbul yabancılar için Türkçe ders kitabı. İstanbul: İstanbul Üniversitesi Dil Merkezi Kültür Sanat Basımevi.

Bulut, S. (2012). Anadolu ağızlarında kullanılan kalıp sözler ve bu kalıp sözlerin kullanım özellikleri. Turkish Studies 7(4), 1117-1155.

Bursalı H. \& Ünal Topçuoğlu F. (2015). Çizgi dizilerin 5. ve 6. sınıf öğrencilerinin söz varlı̆̆ına katkısı. Mustafa Kemal Üniversitesi Sosyal Bilimler Dergisi, 12 (29), 60-74.

Canbulat, M. \& Dilekçi, A. (2013). Türkçe ders kitaplarındaki kalıp sözler ve öğrencilerin kalıp sözleri kullanma düzeyleri. Turkish Studies, 8 (7), 217-232.

Çelebi, V. (2014). Gündelik dil felsefesi ve Austin'in söz edimleri kuramı. Beytulhikme An International Journal of Philosophy, 4(1), 73-89.

Çotuksöken, Y. (1994). Deyimlerimiz, ìstanbul: Özgül Yayınevi.

Çotuksöken, Y. (2002). Türkçe üzerine denemeler ve eleştiriler 1. İstanbul: Papatya Yayıncılık.

Gökdayı, H. (2008). Türkçede kalıp sözler. Bilig Türk Dünyası Sosyal Bilimler Dergisi, 44 89-110.

Gökdayı, H. (2011). Türkçede kalıp sözler. İstanbul: Kriter Yayınevi.

Günay, D., Fidan, Ö., Çetin, B., \& Yıldız, F. (2014). Izmir yabancılar için Türkçe ders kitabı. i̇stanbul: Papatya Yayıncilık.

Güvenç, B. (1996). Türk kimliği. İstanbul: Remzi Kitabevi.

Kıran, Z. \& Eziler-Kıran, A. (2013). Dilbilime giriş. Ankara: Seçkin Yayınevi.

Kula, O. B. (1996). Dilin kültürelliği ya da kültürün dilselliği. Bilim ve Ütopya, 23, 46-47.

Kurt, C., Aygün, N., Leblebici, E., \& Altınkaynak-Coşkun, Ö. (2009). Yeni Hitit yabancılar için Türkçe ders kitabı 1. Ankara: Ankara Üniversitesi Basımevi.

Levinson, S. (1992). Pragmatics. Cambridge: Cambridge University Press.

Özdemir, E. (2000). Erdemin başı dil. Ankara: Bilgi Yayınevi.

Tüm, G. \& Sarkmaz, Ö. (2012). Yabancı dil Türkçe ders kitaplarında kültürel öğelerin yeri. Hacettepe Üniversitesi Eğitim Fakültesi Dergisi, 43, 448-459.

Ünsal, G. (2013). Dil öğretiminde kalıp sözler ve çevirisi. Turkish Studies 8(8), 1383-1394.

Vardar, B. (Ed.). (2002). Açıklamalı dilbilim terimler sözlüğü. İstanbul: Multilingual Yayınevi.

Wray, A. (2002). Formulaic language and lexicon. Cambridge: Cambridge University Press.

Yazııı Okuyan, H. (2012). Illköğretim Türkçe ders kitaplarında bir kültür aktarımı aracı olarak kalıp sözlerin kullanımı üzerine bir inceleme. Türkiye Sosyal Araştırmalar Dergisi 3(3), 31-46.

Yıldııı, A. \& Şimşek, H. (2005). Sosyal bilimlerde nitel araştırma yöntemleri (5th ed.). Ankara: Seçkin Yayınevi. 